NBER WORKING PAPER SERIES

U.S. COMMERCIAL BANKS

AND THE DEVELOPING

COUNTRY DEBT CRISIS

Jeffrey Sachs

Harry Huizinga

Working Paper No. 2455

NATIONAL BUREAU OF ECONOMIC RESEARCH

1050 Massachusetts Avenue

Cambridge, MA 02138

December 1987

The research reported here is part of the NBER's research program in International Studies. Any opinions expressed are those of the authors and not those of the National Bureau of Economic Research. Support from the Ford Foundation, the Tinker Foundation Incorporated, and the Rockefeller Brothers Fund is gratefully acknowledged. 
NBER Working Paper \#2455

December 1987

\section{U.S. Commercial Banks and the Developing Country Debt Crisis}

\section{ABSTRACT}

The major theme of this paper is that the commerclal banks have weathered the debt crisis, while many debtor countrles remain in economic paralysis or worse. There is a growing consensus that much of the LDC debt will not be fully serviced in the future, and that consensus is reflected in at least two ways: in the discounts observed in the secondary market prices for LDC debt, and in the discounts in the stock market pricing of banks with exposure in the LDCs.

Jeffrey Sachs

Department of Economics

Harvard University

Cambridge, MA $0 ? .138$
Harry Huizinga

Deoartment of Economics

Harvard University

Cambridge, MA 02138 
The debt crisis of the less developed countrles (LDCs) broke out in August 1982, with the announcement by Mexico that it would be unable to meet its debt obligations then falling due. Since then, more than 40 developing countries have been forced to reschedule their debts with commercial bank creditors and to seek additional lending and other forms of relief from the international financial community. ${ }^{1}$ From its inception, the debt crisis has been viewed as posing serious risks to the major U.S. commercial banks, since the exposure of these banks in the developing countries has significantly exceeded their total bank capital.

Table 1 shows the exposures of the U.S. banks in the major debtor countries as of the end of 1986 . The exposure is divided by size of bank (the large money center banks versus the rest of the U.S. banks), and by type of claim (on the public sector of the LDCs versus private sector borrowers). Note the high concentration of the claims. The exposure of the top 9 banks in just the top 4 countries (Argentina, Brazil, Mexico, and Venezuela) accounts for $\$ 41$ billion, or 45 percent of total U.S. exposure in the developing countrles shown in the table. The top 9 banks account for a remarkable 65 percent of total exposure of U.S. banks in Latin America. Note also that sovereign loans (i.e. loans to foreign public sector borrowers) account for about two thirds of U.S. bank lending to the LDCs. ${ }^{2}$

As described in Sachs (1986), the debt management strategy pursued by the U.S. and the official financial community after 1982 
Table 1. Claims of U.S. banks in the debtor countries. (millions of dollars)

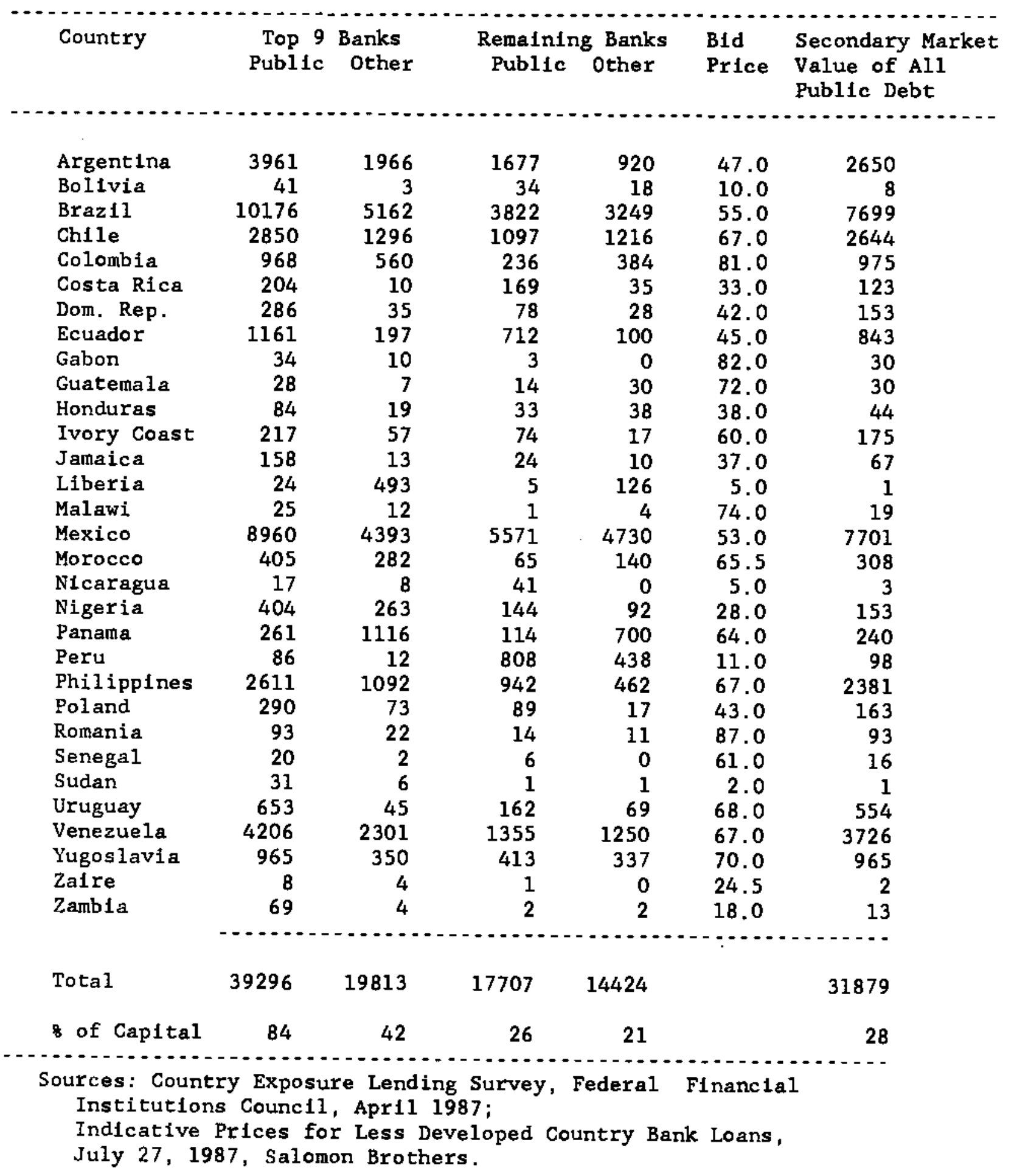


has been geared towards the protection of the large commercial banks, at least on a short-run accounting basis. The welght of U.S. foreign policy has been to maintain current interest servicing by the debtor countrles to the U.S. banks, and to avold any explicit debt forgiveness or even capitalization of interest payments. ${ }^{3}$ U.S. regulators have also taken an easy line in applying prudential standards to banks with large LDC exposures. The banks have been allowed to carry almost all of their LDC exposure on the books at face value, and they have been able to count as current income all the interest payments they recelve on the loans, even when the interest payments are made possible only by new "1nvoluntary" loans to the debtor country.

By acting as if all is normal regarding the bulk of LDC loans, the regulators have hoped to accomplish three things: to keep the debtor countries from halting interest payments or promoting alternative proposals for debt forgiveness; to keep the banks from withdrawing precipitously from the debtor countries; and to keep depositors and other creditors of the banks from withdrawing precipitously from the banks. In a limited sense this strategy has worked. Worst-case scenarlos of financlal panic have been avoided, and the banks have been given time to increase their capital ratios. U.S. bank exposure in the problem debtor countries as a percent of the book value of primary capital has declined significantly since 1982, as shown in Table 2 .

At a deeper level, however, the regulatory treatment has not hidden certain economic truths from debtors, the banks, or the 
Table 2. Exposure in the debtor countries as a percentage of bank capital, and bank capital, varlous perlods 1982 - 1986.*

Region

End-1982

Mid-1984

End-1986

All U.S. Banks
A11 LDC's

Latin America

Africa

A11 LDC's

Latin America

Africa

All LDC's

Latin America

Africa

Top 9 Banks

Al1 Other Banks
186.5

118.8

10.2
156.6

102.5

7.7

Top 9 Banks

287. 7

176.5

19.3
246.3

157.8

14.3
94.8

68.0

3.2

153.9

110.2

6.0
A11 Other Banks

$\begin{array}{rrr}116.0 & 96.1 & 55.0 \\ 78.6 & 65.2 & 39.7 \\ 3.8 & 3.3 & 1.3\end{array}$

Total Bank Capita1 (billions)
29.0
34.1
46.7
41.6
50.6
69.4

Source: Federal Financial Institutions Examinations Counc11, "Exposure Lending Survey." Mid-1084 data from statistical release of October 15, 1984; End 1986 data from release of April 24, 1987.

* Exposures are amounts owed to U.S. banks after adjustments for guarantees and external borrowing. Total exposures are calculated for all LDC's (Opec, Nonoil Latin America, Nono11 Asia, Nono1l Africa); Latin Anmerica (Nonoi1 Latin America plus Ecuador and Venezuela); and Africa (Nonoll Africa plus Algerla, Gabon, Libya, and Nigeria). 
marketplace more generally. Despite the officlal optimlsm of the U.S. and the creditor communtty regarding the debt crisis, and the seemingly relaxed attitudes of the U.S. regulators, most market particlpants have conceeded that much of the LDC debt will not be fully serviced on market terms in the longer term. Moreover, the regulatory laxness may have had deleterious effects on the adjustment of the U.S. banks to the crisis, by allowing the banks to move slowly In the process of rebuilding their captal base. Some banks have been allowed to pay unduly large dividends at the expense of their capital in recent years, since they have been allowed to overstate their economic incomes.

A good Indicator of long-term expectations regarding LDC claims Is the price of those claims on the secondary market. Column 5 of Table 1 records the secondary bid price for a $\$ 100$ claim, as of July 1987. The price for claims on the major debtors, Argentina, Braztl and Mexico, is in the range of $\$ 45-55$. The welghted average price for the entire U.S. bank portfollo, welghting by exposure in the various countries, is $\$ 55.9$ per $\$ 100$ clatm. (Spectfically, the $\$ 57.0$ billion of U.S. bank exposure in Table 1 had a secondary market value of $\$ 31.9$ billion). 4

A major theme of this paper is that the stock market prices of the commercial banks also reflect the secondary-market valuation of the LDC exposure. Spectfically, since the stock market values the commercial banks according to the value of the underlying portfolios of the banks, equity prices of banks have weakened In line with the growing pessimism over the value of the LDC clatms. ${ }^{5}$ This is an 
Important finding since many bankers and U.S. Administration officials have argued erroneously that the secondary market price of LDC debt is a poor guide to more general market sentiments concerning the LDC debt. In fact, the secondary market prices of the debt and the Implicit stock market valuations of the debt are closely in line as of mid-1987.

The fact that stock market prices have been discounted helps to explain the current eagerness of banks to sell their LDC exposures at a discount, since the banks can accept a capital loss in the books without further depressing the market value of the bank. It appears that Citicorp's decision this past spring to increase its loan loss reserves against Latin American exposure (an action that was followed by the other major banks in the U.S. and abroad) is a prelude to a policy of selling off the LDC exposure at a significant discount. As we discuss later, this new pollcy of selling off debt may have Important Implications for public policy in this area.

We organize our discussion in the following manner. The next section of the paper briefly considers some of the underlying causes for the growing market discount on the LDC debt. Then, we turn to an analysis of how the banks and regulators have responded to the crisis since 1982. Next we examine the effects of the crisis on the market valuation of the commercial banks, showing the clear evidence that the stock market is now valuing the $L D C$ debt at the substantial discounts reflected in the secondary market. In the final section, we explore some of the implications of the market discount for the future of debt negotiations and for various debt relief proposals. 
Why the LDC Debt Sells at a Discount

Many of the shortcomings of the current debt management strategy were outlined in Sachs (1986). It was pointed out in that study that most of the optimistic assessments of the debt crisis ignored the internal economic dislocations caused by the large debt overhang. Most optimistlc observers, such as William cline, have viewed the problem for the debtor countries purely in terms of various external parameters: OECD growth, world Interest rates, and global commodities prices. They have failed to factor in the economic and political disarray within the debtor countries that has resulted from, or has at least been greatly aggravated by, the debt crisis: low rates of national savings and investment, large budget defictts, recourse to inflationary finance. ${ }^{6}$

Most of the debtor countries have little prospect of servicing a large proportion of the interest due on the1r external debt in the next few years. In the past five years, the debtor countries have made significant net resource transfers to the creditors (in Latin America, amounting to about 5 percent of GNP per year). But as we see in Table 3, these transfers have not been enough to prevent a rise in the debt-export ratios of the major debtor countries, not the fall that was predicted in influential studies in 1983 and 1984 by Cline and DeVries.

Recently, some primary commodity prices have increased significantly, apparently in a lagged response to the depreciation of the dollar, giving hope that the export prospects of the LDCs will 
Table 3. External debt-to-export ratio's.

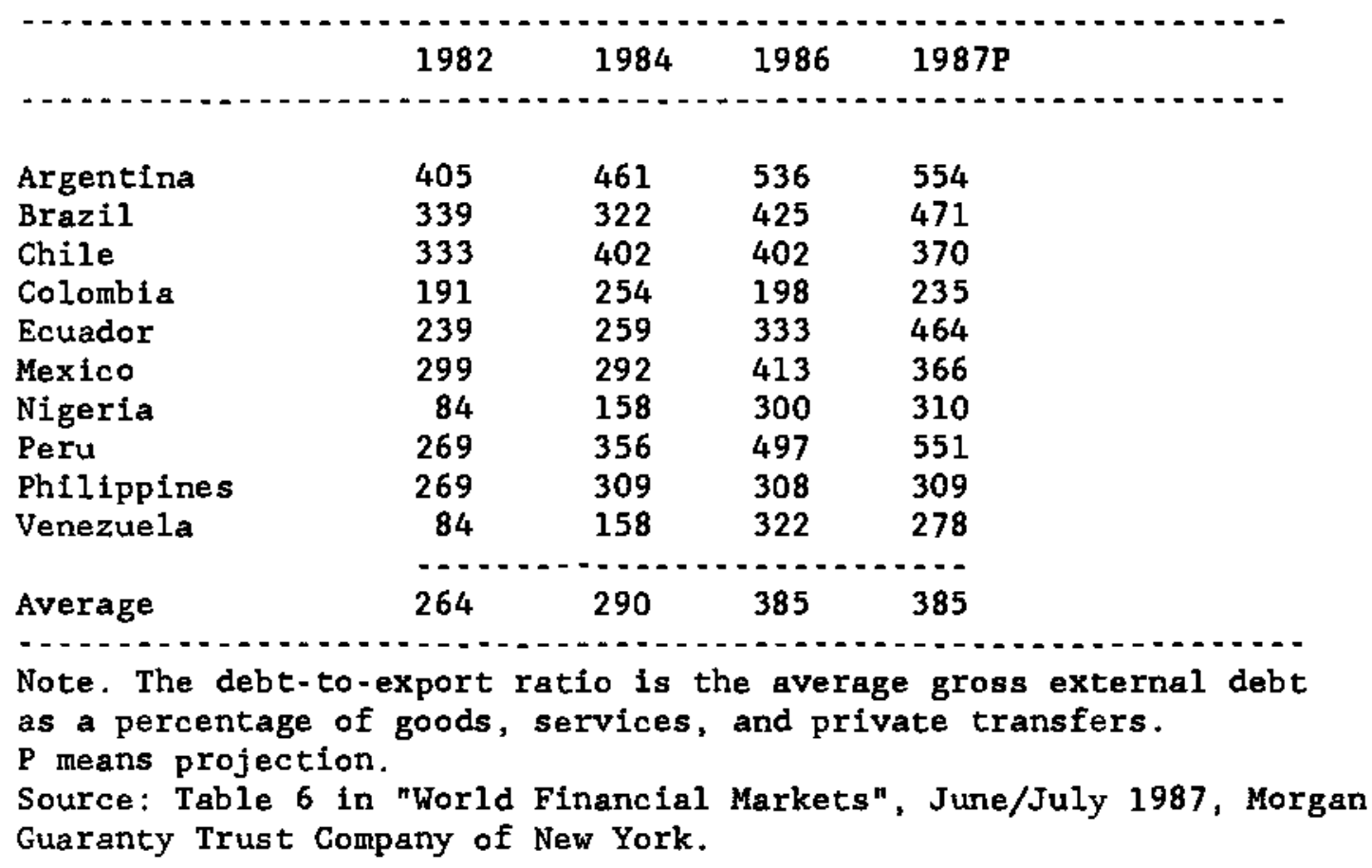


significantly improve. Ironically, however, most of the improvement in prices has been for non-food primary commodities produced mainly in the developed countries (e.g. primary metals) or in the developing countries in Asia, most of which are not in crisis. ${ }^{7}$ The prices for the main Latin American commodity exports (for sugar, wheat, beef, coffee, cocao) continue to be deeply depressed, so that the modest commodity price recovery has so far given little respite to the crisis. Moreover, international interest rates have risen significantly in 1987.

Moreover, many of the major debtor countries are in fiscal turmoil, even after the sharp cuts in government spending in recent years. The interest due on the foreign debt constitutes a large proportion of budgetary expenditures (around 30 percent of government spending in many of the debtor countries), and stands in the way of budgetary reform. ${ }^{8}$ The voters in the new democracies in Latin America are not content to absorb further austerity for the sake of foreign creditors. The recent rise in world interest rates will intensify the pressures. For several years, inflation has been at triple digit annual rates in Argentina, Brazil, and Peru, and has recently topped 150 per cent annual rate in the spring and sumner of 1987 in Mexico. The 20,000 per cent hyperinflation in Bolivia was brought under control only after Bolivia's complete cessation of interest payments on the external bank debt.

One result of the internal economic disarray has been a burgeoning of unilateral actions on the debt, particularly in the democratic countries in Latín America. Bolivia, Brazil, Costa Rica, 
the Dominican Republic, Ecuador, Honduras, and Peru have all unilaterally suspended part or all of the interest servicing on their foreign debt in the past two years. In the two major debtor countries that have not suspended (Argentina and Mexico), the banks have found it necessary in 1987 to relend almost all of the interest due in order to forestall a unilateral suspension of payments. Mexico recelved approximately $\$ 6$ billion in bank credits and Argentina recently signed an agreement for $\$ 2$ billion in new bank credits. 9

Three other large debtors, Chile, the Philippines, and Venezuela have been servicing their debts recently without substantial refinancing of interest. Chile, of course, is not so much a model debtor country as a model authoritarian country: the government can indeed impose the requisite domestic austerity to make it possible to service the debt. ${ }^{10}$ In the Philippines, the government was fearful of tough negotiations because of the internal instability of the Aquino government. 11 The Aquino government therefore signed a rescheduling agreement in 1987 with no concerted lending from the banks. There is now a good chance that a unilateral partial suspension of debt servicing will be declared by the Philippine Congress. In Venezuela as well, the government is under fferce political pressure to abandon its recent debt rescheduling agreement. Even the government's own political party has called for a reopening of negotiations with a view towards achieving debt relief.

In the cases where debt agreements have been reached in the past year, the terms for the banks on aspects other than new lending have also worsened. In the first round of reschedulings (1983), debt was 
recontracted with an interest rate spread of about 2 percentage points ovar LIBOR (the London Interbank offered Rate). In the second round of reschedulings $(1984-85)$, the spreads were reduced to about 1.2 percentage points. In the recent round of reschedulings, the spreads have fallen further, to less than one percentage point. Similarly, commissions have declined, and the maturities and grace periods on the rescheduled debts have also increased. 12

It is thus not difficult to understand the growing discount on LDC paper in the secondary market. The economies in most cases are not getting better, and the countries are increasingly demanding more concessional terms in reflection of that reality. Many are simply taking unilateral actions in response to their deepening continuing crisis. Moreover, the international macroeconomics environment, particularly regarding interest rates and commodities prices, remains unsatisfactory. Price quotations on the secondary market have only been avallable on a detalled basis for the past year (several investment banks now circulate price sheets), but all indications suggest that the discount has been growing, 1.e. the prices falling, over the past few years, as shown by the data in Table 4 .

On a cross-country basis, the magnitude of the discount on the LDC debt seems to be well explained by four variables: the debt-GNP ratio, denoted D/GNP (the debt-export ratio works about as well); the rate of real GNP growth, GNPGROWTH; a dummy varlable sUSP indicating whether the country has unilaterally suspended debt service payments; and a dummy variable (ATRR) indicating whether U.S. bank regulators have mandated an allocated reserve (1.e. a writedown) for the 
Table 4. Secondary market prices for LDC debt (per \$100).

\section{November 1985 August 1986 April 1987 July 1987 October 1987}

$\begin{array}{lrllll}\text { Argentina } & \text { n.a. } & 66 & 60 & 47 & 34 \\ \text { Brazil } & 75-83 & 76 & 63 & 55 & 38 \\ \text { Mexico } & 78-82 & 56 & 59 & 53 & 47 \\ \text { Peru } & 32-36 & \text { n.a. } & 17 & 11 & 5 \\ \text { Ecuador } & \text { n.a. } & 65 & 56 & 45 & 30\end{array}$

Sources; November 1985, Econonlst Magazine (11/16/85); August 1986, Euromoney 1987, Salomon Brothers, Inc., "Indicative Prices for Less Developed Country Bank Loans," (4/20/87, 7/27/87, and 10/6/87), bld prices. 
country's assets on the books of the U.S. banks. The following simple regression model does well in accounting for the secondary market prices as of July 1987:

\author{
Price - $77.2-9.6$ ATRR - 17.2 SUSP - .15 D/GNP + 2.2 GNPGROWTH \\ (16.3) (1.2) (6.3) (2.7) (2.2) \\ $R^{2}-0.84$ \\ 28 observations
}

(The variable susP is a dummy variable equalling 1 if the country suspended interest payments in 1987, and 2 if the country suspended interest payments prior to 1987 and 1s still in suspension.) According to the equation, a claim on a debt-free LDC with 6 percent annual growth would command a secondary market price of $\$ 90.4$ ( $\$ 77.2$ $+6 \times 2.2$ ). On the other hand, a country like Bolivia with a D/GNP ratio of 136.8 , a per capita GNP growth of -4.5 per year, a required writeoff for U.S. banks (ATRR-1), and more than two years in debt suspension ( $\operatorname{SUSP}=2$ ), has a predicted price of $\$ 3.7(-\$ 77.2-9.6$ $17.2 \times 2-.15 \times 136.8-2.2 \times 4.5$ ), compared with an actual price of $\$ 10$.

A key problem with interpreting the secondary market prices involves the role of SusP. On its face, the pricing equation suggests that a country can manipulate the secondary market price of its debt by suspending debt servicing. To the extent that debt service relief is then tied to the secondary market price of debt, as in some of the 
relief proposals discussed later, there might be the moral hazard problem of countries unilaterally suspending debt payments as a strategic maneuver to benefit from relief. The moral hazard argument is overdrawn, however, to the extent that SUSP is proxying for other country characteristics that make debt servicing particularly difficult for that country: political instability, adverse export structure, financial collapse, etc. In that case, SUSP is simply another indicator of "ability to pay" rather than an manipulable strategic variable.

Patterns of Debt Management by the Banks and Bank Regulators

In this section, we consider the response of the commercial banks and bank regulators to the crisis since 1982. The key facts about this response are well known. The banks have virtually stopped making new loans to the problem debtor countries, with the little lending that remains taking place in the context of specific bailout packages. During this period of little lending, the banks increased their primary capital base, and thereby reduced the ratio of IDC exposure to capital.

In our summary of bank behavior, we focus on three varlables: changes in bank exposure in the IDCs, bank earnings, and changes in the capital base of the banks.

Bank Exposure in the LDCs

The change in bank lending behavior is shown in Table 5. U.S. bank exposure to the problem debtor countrles fell in absolute dollar 
Table 5. Growth rates of bank lending 1979 - 1986.

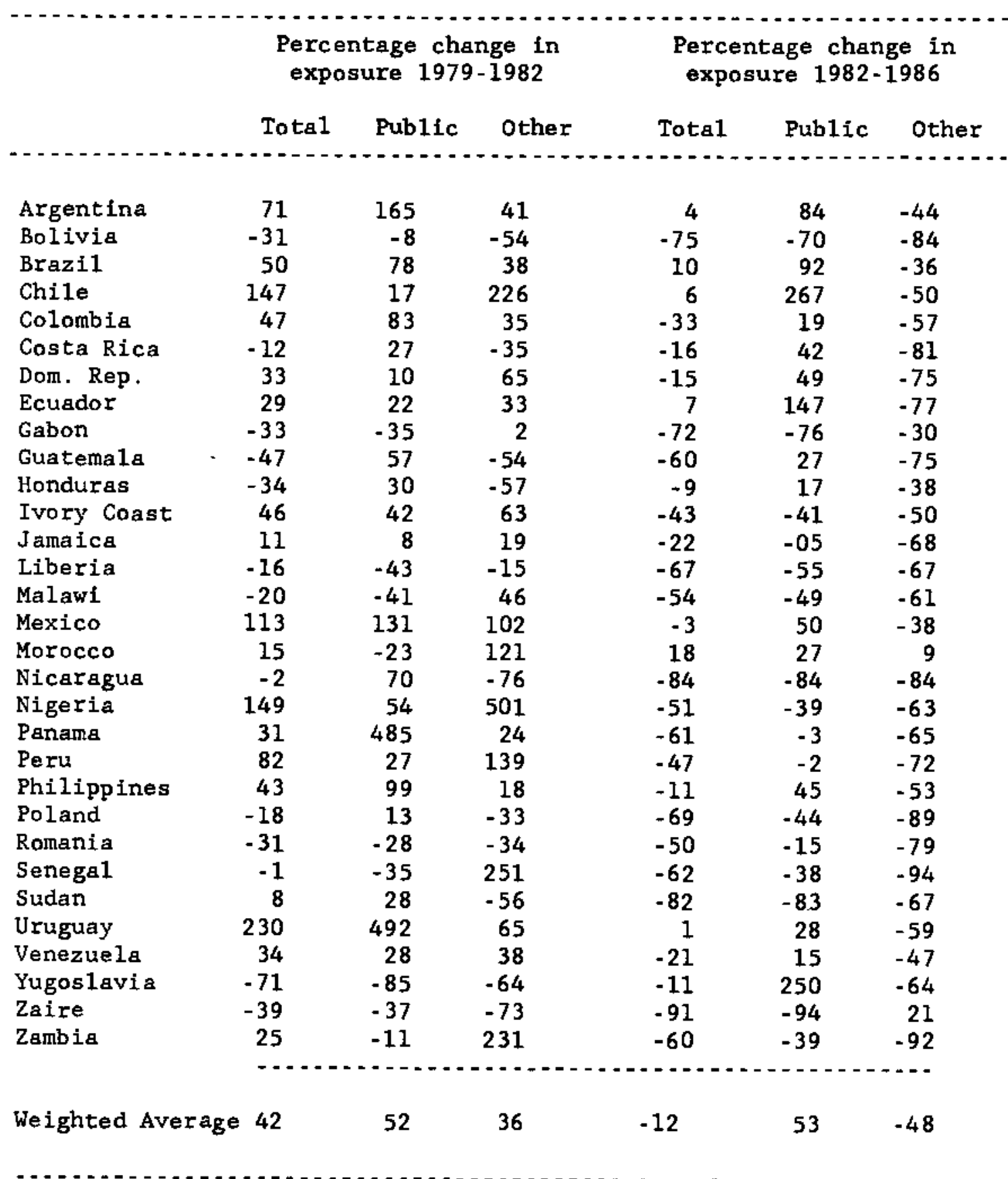

Sources: Country Exposure Lending Survey, Federal Financial

Examination Council, various issues. 
amount during the period $1982-86$, after rising rapidly during the period 1979-82. The absolute decline in lending belies one of the myths of the management of the crisis, that the banks have continued to provide net "new money" to the debtor countries though at a reduced rate of increase. (Remember that the widely publicized negotiated loan agreements are termed "new money" packages).

The common perception that the banks have continued to lend to the IDCs on a net basis can best be explained by looking at a breakdown of the bank loans between public sector borrowers and private sector borrowers in the LDCs. Claims on the public sector have risen by 53 percent during 1982-1986, while claims on the private sector have decline by 48 percent. This difference reflects the fact that the widely publicized concerted lending agreements in recent years have been loans to governments. But at the same time that the banks have been providing "new money" to governments, they have been withdrawing loans from the private sector.

Three other factors can also account for the differential growth in claims on the public and private sectors. To some extent, private sector debts have become public sector debts as governments have taken over some of the foreign obligations of the private sector since the beginning of the debt crisis. Secondly, the decline in exposures to the private sector represents, in part, a writeoff of claims on the private sector, rather than an amortization of loans. Third, declines in exposure also reflect sales by the banks of their LDC claims, or declines due to debt-equity swaps. Given the published data it is impossible to distinguish changes in exposure due to new loans, 
amortizations, writeoffs, sales, swaps, or public-sector assumptions of private sector debt.

We should stress that the notion of "new money" is also misleading when account is taken of the fact that most "new money" packages after 1982 have involved considerably less in new loans than is due to the same creditors in interest. Thus, even when Mexico or Argentina gets a "new loan" after months of hair-raising negotiations, the check is still written by the debtor governments to the commercial banks, rather than in the other direction. Technically, the net resource transfer (equal to new lending net of amortizations and interest payments) to the countries is negative. The fact of negative net resource transfers points up one of the fallacies in a popular argument as to why debtor countries should not default. It is sometimes said that if a country defaults, it will be not be able to attract new bank money. Th1s is obviously not a major concern to a debtor country if the reduction in interest payments achieved by default systematically exceeds the amounts of new money that the country is able to borrow by not defaulting!

The pattern of concerted lending packages among the debtor governments also highlights Keynes' famous adage that "If you owe your bank 100 pounds, you're in trouble, if you owe your bank 1,000,000 pounds than he's in trouble". Very systematically, it is the countries with large debts that have been able to bargain for new lending from the banks. This is evident from the data in Table 6. For each country, we measure the size of concerted loans in year $t\left(C L_{t}\right)$ as a proportion of disbursed debt at the end of year $t-1, D_{t-1}$. On average, the ratio 
Table 6. Medium-term concerted lending as a percentage of debt outstanding and disbursed from financlal markets.

\begin{tabular}{|c|c|c|c|c|c|}
\hline & 1983 & 1984 & 1985 & 1986 & $\begin{array}{r}\text { Average } \\
19831986\end{array}$ \\
\hline Argentina* & 12 & 18 & 0 & 0 & $-\cdots$ \\
\hline $\begin{array}{l}\text { Argentina* } \\
\text { Bolivia }\end{array}$ & $\begin{array}{r}12 \\
0\end{array}$ & $\begin{array}{r}18 \\
0\end{array}$ & $\begin{array}{l}0 \\
0\end{array}$ & $\begin{array}{l}0 \\
0\end{array}$ & $\begin{array}{l}8 \\
0\end{array}$ \\
\hline Brazil & 11 & 14 & 0 & 0 & 6 \\
\hline Chile & 35 & 16 & 9 & 0 & 15 \\
\hline Colombia & 0 & 0 & 29 & 0 & 7 \\
\hline Congo & 0 & 0 & 0 & 9 & 2 \\
\hline Costa Rica & 0 & 0 & 0 & 0 & 0 \\
\hline Dom, Rep. & 0 & 0 & 0 & 0 & 0 \\
\hline Ecuador & 20 & 0 & 0 & 0 & 5 \\
\hline Gabon & 0 & 0 & 0 & 0 & 0 \\
\hline Guatemala & 0 & 0 & 0 & 0 & 0 \\
\hline Honduras & 0 & 0 & 0 & 0 & 0 \\
\hline Ivory Coast & 0 & 0 & 4 & 0 & 1 \\
\hline Jamaica & 0 & 0 & 0 & 0 & 0 \\
\hline Liberia & 0 & 0 & 0 & 0 & 0 \\
\hline Madagascar & 0 & 0 & 0 & 0 & 0 \\
\hline Malawi & 0 & 0 & 0 & 0 & 0 \\
\hline Mexico & 11 & 6 & 0 & 8 & 4 \\
\hline Morocco & 0 & 0 & 0 & 0 & 0 \\
\hline Nicaragua & 0 & 0 & 0 & 0 & 0 \\
\hline Nigeria & 0 & 0 & 0 & 4 & 1 \\
\hline Panama & 0 & 0 & 3 & 0 & 1 \\
\hline Peru & 16 & 0 & 0 & 0 & 4 \\
\hline Philipines & 0 & 18 & 0 & 0 & 5 \\
\hline Senegal & 0 & 0 & 0 & 0 & 0 \\
\hline Sudan & 0 & 0 & 0 & 0 & 0 \\
\hline Togo & 0 & 0 & 0 & 0 & 0 \\
\hline Uruguay & 18 & 0 & 0 & 0 & 5 \\
\hline Venezuela & 0 & 0 & 0 & 0 & 0 \\
\hline Yugoslavia & 41 & 0 & 0 & 0 & 10 \\
\hline Zaire & 0 & 0 & 0 & 0 & 0 \\
\hline Zambia & 0 & 0 & 0 & 0 & 0 \\
\hline
\end{tabular}

For each year, we calculate the ratio of the concerted loan CLt, to the disbursed debt at $t-1, \mathrm{Dt}-1$.

* In 1987 Argentina received a concerted loan amounting to 6 per cent of its 1986 outstanding loans.

Sources: World Debt Tables, 1986-1987 Edition, World Bank;

International Capital Markets, 1986, IMF; 
$\mathrm{CL}_{t} / \mathrm{D}_{t-1}$ is far higher for the large debtors (Argentina, Brazil, Chile, Mexico) than for the rest. Venezuela is a significant exception to this rule, since the current Venezuelan administration has, curiously, never trled to bargain for new money. To summarlze the data In Table 6, the fifteen small debtor countries in the table had 3.4 percent of the debt at the end of 1983 , but have received only 0.3 per cent of the concerted loans during 1984-1986.

\section{Bank Earnings}

Ironfcally, during 1982-86 the debt crisis did not have a serious adverse effect on the reported current earnings of the banks, even though it fundamentally called into question the very solvency of the banks. While dotibts grew about the long-term willingness of the debtor cotuntrles to service their debts, and while principal repayments were postponed for many years in the course of reschedulings, most of the LDCs continued to service the interest due, though sometimes only after the banks loaned the countrles much of the money needed to make the interest payments. Even when interest payments were clearly tied to new loans, the bank regulators allowed the banks to report the interest received in full as current income (rather than, for example, requiring that part of the interest be allocated to loan loss reserves, and therefore not be counted as current incone)

The reported net income for the top nine banks is shown in Table 7. We see that reported income rose for most of the major banks, with the conspicuous exception of Bank of America, which suffered major 
Table 7. Reported net income for 10 large banks (millions).

\begin{tabular}{|c|c|c|c|c|c|c|c|c|}
\hline & 80 & 81 & 82 & 83 & 84 & 85 & 86 & 87 \\
\hline Citicorp & 449 & 531 & 723 & 860 & 890 & 998 & 1058 & -999 \\
\hline BankAmerica & 643 & 445 & 390 & 391 & 346 & 337 & -518 & -929 \\
\hline Chase Manhattan & 354 & 412 & 308 & 430 & 406 & 565 & 585 & -832 \\
\hline Manufacturer's $\mathrm{H}$. & 229 & 252 & 295 & 337 & 353 & 408 & 411 & -1103 \\
\hline J.P. Morgan & 342 & 348 & 394 & 460 & 538 & 705 & 873 & 952 \\
\hline Chemical NY & $\begin{array}{l}174 \\
181\end{array}$ & 205 & 241 & 301 & 341 & 390 & 402 & -703 \\
\hline $\begin{array}{l}\text { Security Pacific } \\
\text { First Interstate }\end{array}$ & $\begin{array}{l}181 \\
225\end{array}$ & $\begin{array}{l}206 \\
236\end{array}$ & $\begin{array}{l}234 \\
221\end{array}$ & $\begin{array}{l}204 \\
247\end{array}$ & $\begin{array}{l}291 \\
276\end{array}$ & $\begin{array}{l}323 \\
313\end{array}$ & $\begin{array}{l}386 \\
338\end{array}$ & $\begin{array}{r}112 \\
-165\end{array}$ \\
\hline Bankers Trust & 214 & 188 & 223 & 260 & 307 & 371 & 428 & -151 \\
\hline First Chicago & 63 & 119 & 137 & 184 & 86 & 169 & 276 & -438 \\
\hline
\end{tabular}

Sources: Company Annual Reports; Compustat; Keefe Bankscan, July 17, 1987 , Keefe, Bruyette \& Woods, Inc. 
losses on its domestic loan portfolio. In some cases the measured income was even enhanced by the crisis, since in 1983 and 1984 many of the rescheduling agreements involved significant front-end fees and an increase in the interest rate spreads built into the loan agreements. Table 8 shows the share of LDC assets that were on a nonaccrual basis as of the end of $1986 .^{13}$ Note that this ratio is only slightly higher than the ratio of domestic loans on a nonaccrual basis.

In assessing the effects of the debt crisis on measured earnings, a distinction must be drawn between the bank claims on the public sectors and the private sectors in the LDCs. For the sovereign loans, the vast bulk of interest due has been paid on a timely basis. Among the major debtors prior to 1987, only Argentina fell behind on interest payments on sovereign debt, in 1984 and early 1985. In 1987, Brazilian sovereign debt has been in suspension since February 20. As for private debt, all of the major debtors except for Braz1l (i.e. Argentina, Mexico, and Venezuela) have had periods of fairly significant arrearages on private debt, though by the end of 1986 most of those arrearages had been eliminated. Also, an unknown proportion of the private debt has been lost forever in the form of firm-level bankruptcies, or in debt workouts with the creditors at significantly concessionary rates.

Only in 1987 have the income statements of the banks begun to suffer, as some of the larger debtors (especially Braz11) have suspended interest payments, and more importantly, as significant additions to loan loss reserves have been made. Because of loan loss provisions, the large U.S. banks posted losses of about $\$ 10$ billion in 
Table 8. Percentage of exposure to Argentina, Ch1le, Mexico and Venezuela on nonaccrual and percentage of other assets on nonaccrual

for 10 large U.S. banks, end of 1986 .

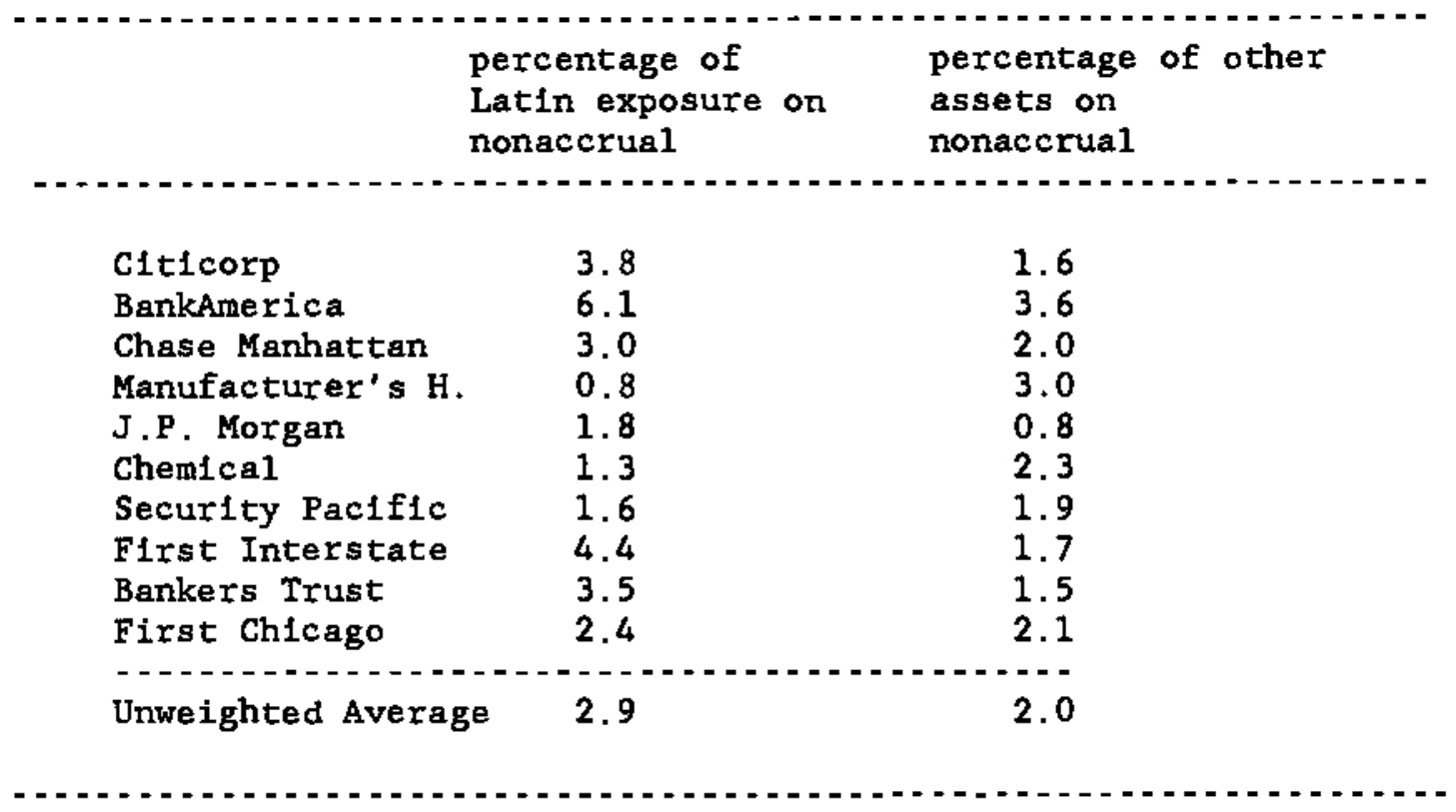

Source: Revlew of Bankperformance, 1987 Edition, Salomon Brothers. Note. Th1s table has been corrected during revision of the paper. 
the second quarter of 1987.

It is useful here to make clear the meaning of the recent provisioning by Citicorp and the other leading banks. Table 9 shows the size of provisions taken, and the share of Latin American exposure that is now "covered" by the the loan loss reserves. This share is calculated by taking the banks' total loan loss reserves, and subtracting off all domestic nonperforming assets. The net reserves are then compared with the exposure in Latin America. Citicorp's stated goal was to cover 25 percent of its Latin American exposure.

since the provisions are "unallocated" (1.e. not tied to particular loans, or even to particular countries), they do not Involve a writedown in value of particular assets. (A fortiori, they do not involve any forgiveness by the banks of any part of the debts owed by the developing countries!). The increase in provisions reduces reported income of the banks, but it does not reduce taxable income, since taxable income is not reduced by a general, unallocated provision. On the balance sheet, the increased provisioning is a transfer from shareholder's equity to loan loss reserves. As pointed out below, this shift does not affect measured primary capital of the bank.

The provisioning does not affect the cash flow of the banks. In that sense it is a cosmetic move only. In the future, if the banks write off some portion of their LDC exposure (e.g. by selling the assets at a discount, or by settling with the countries at below market terms), they will be able to charge the losses to the loan reserves without any effect on reported income at the future date. At 
Table 9. Loan loss reserves net of domestic non-performing assets, and as a percentage of outstandings to Argentina, Brazil Mexico and Venezuela for 9 large U.S. banks.

\begin{tabular}{|c|c|c|c|c|c|}
\hline & $\begin{array}{l}\text { Loan loss } \\
\text { reserve } \\
\text { end-1986 } \\
\text { (millions) } \\
\text { (1) }\end{array}$ & $\begin{array}{l}\text { Loan loss } \\
\text { reserve } \\
\text { addition, } \\
\text { l987 } \\
\text { (millions) } \\
\quad(2)\end{array}$ & $\begin{array}{l}\text { Domestic } \\
\text { non- } \\
\text { performing } \\
\text { assets } \\
\text { (millions) } \\
\quad(3)\end{array}$ & $\begin{array}{l}\text { Net loan loss } \\
\text { loss } \\
\text { reserve } \\
\text { (millions) } \\
(4)- \\
(1)+(2)-(3)\end{array}$ & $\begin{array}{l}\text { Net reserve as a } \\
\text { percentage of } \\
\text { exposure } \\
\text { to Latin four }\end{array}$ \\
\hline $\begin{array}{l}\text { Citicorp } \\
\text { BankAmerica } \\
\text { Chase Manhattan } \\
\text { Manufacturer's H. } \\
\text { J.P. Morgan } \\
\text { Chemical } \\
\text { Security Pacific } \\
\text { First Interstate } \\
\text { Bankers Trust }\end{array}$ & $\begin{array}{r}1698 \\
2172 \\
1065 \\
1008 \\
910 \\
669 \\
729 \\
536 \\
591\end{array}$ & $\begin{array}{r}3000 \\
1100 \\
1600 \\
1700 \\
0 \\
1100 \\
500 \\
750 \\
700\end{array}$ & $\begin{array}{r}2022 \\
3148 \\
980 \\
1761 \\
316 \\
1015 \\
1132 \\
1238 \\
526\end{array}$ & $\begin{array}{r}2676 \\
124 \\
1685 \\
947 \\
594 \\
754 \\
97 \\
48 \\
765\end{array}$ & $\begin{array}{r}27 \\
2 \\
26 \\
14 \\
14 \\
18 \\
7 \\
4 \\
28\end{array}$ \\
\hline average & 1042 & 1161 & 1349 & 854 & 16 \\
\hline $\begin{array}{l}\text { Note, Data on l } \\
\text { ali other dat } \\
\text { Sources: New Yo } \\
1987 \text { Edition, }\end{array}$ & $\begin{array}{l}\text { are for } \\
\text { c Times, } \\
\text { alomon } \mathrm{Br}\end{array}$ & $\begin{array}{l}\text { serves are } \\
\text { and } 1986, \\
\text { uly 2, } 1987 \\
\text { others. }\end{array}$ & Review of & Bankperformar & \\
\hline
\end{tabular}


that point the capltal base of the bank would shrink, and the taxable earnings of the bank would fall in line with the writeoff. Thus, by accepting large reported losses now, the banks will be better placed to report positive earnings in the future, even if the LDC loans go sour.

Capttal Adequacy

Even before the debt crisis hIt, U.S. bank regulators had judged that the capital-asset ratios of U.S. banks were Insufficient. New regulations promulgated in the early 1980 s called for a rise in the ratio of primary capital to total assets, from the prevailing low levels of about 4 percent to levels of 5.5 percent. Total capital (equal to primary capital plus certain types of qualifying subordinated debt) was required to rise to 6.0 percent of total bank assets.

A vast literature on banking regulation has stressed the need for such prudential limits. ${ }^{14}$ Banks are highly leveraged Institutions, giving rise to the possibilfty of large fluctuations in net worth, and also to various incentive problems. A small change in the average value of the bank's assets can dramatically reduce the net worth of the bank, and even drive the bank into bankruptcy. ${ }^{15}$ Moreover, since banks are operating with borrowed funds, and since most of those funds are Insured by federal deposit insurance, bank managers may have the incentive to take excessive risks 1 f bank capltal is too low a share of total assets. If the net worth of the bank is low relative to the 
total assets of the bank, then the bank managers (on behalf of the shareholders) have the Incentive to take large gambles with borrowed funds. If the gamble goes well, the shareholders enjoy an enormous proportional return to their assets. If the gamble goes poorly, the shareholders lose only the small amount of the net worth, and the deposit insurance institution must make up the difference to the depositors.

Another aspect of prudential supervision, one that was obviously overlooked in the 1970 s and early 1980s, is the requirement that the bank not commit more than 15 percent of bank capltal in loans to any borrower. In fact, the loans to the Brazilian government and to the Mexican government greatly exceeded 15 percent of capital for many of the large U.S. banks, but the rule was not Invoked since the regulators allowed the banks to treat the varlous offlclal borrowers (e.g. parastatals, central government, development banks, etc.) in Mexico and Brazil as distinct borrowers even though all of the institutions were backed by the same government guarante ${ }^{16}$. In the event, all of the loans to the various officlal borrowers in each of the countries went bad at the same time. Moreover, repayments on private-sector debts were generally suspended at the same time as repayments on the debts of offictal borrowers, and a considerable amount of private-sector debt was taken over by the pub1ic sector (often on the behest of the commercial banks).

On paper, the capital adequacy rules have been enformen, and the cap1tal base of the U.S. banks has been strengthened. But at least some of this is due to accounting convention rather than to an actual 
strengthening of bank balance sheets. For bank capital to protect the bank from bankruptcy and to forestall adverse Incentive problems, the bank capital should consist mostly of shareholder's equity, and it should be properly valued. In fact, the measure of primary capital used for capital adequacy requirements includes both equity and loan loss reserves. Thus, even when the banks make loan loss provisions because they anticipate future losses on assets, measured primary capital is unaffected, because the loan loss provision Involves a transfer between shareholders equity and loan loss reserves, both of which are fully counted in primary capital. Moreover, since the LDC claims are carried in the books at full face value, and until recently were not covered by loan loss provisions, the book values of shareholders equity clearly overstated the market value of shareholders equity on this account.

Thus, the pattern of U.S. banks has been one of rising capital-asset ratios during 1982-87, as shown in Table 10, but with a significant decline in the ratio of shareholder's equity to assets as of mid-1987 (Table 11), when the banks made a substantial increase in loan loss reserves. The conclusion seems to be that the regulators have not succeeded in raising the ratio of shareholder's equity to total assets by much at all in the 1980s. Since the loan loss reserves on the Latin American claims still cover no more than 25 percent of the Latin exposure, and since the markets are signaling a discount on the debt of perhaps 45 to 50 percent, it seems clear that shareholders equity is still overstated on account of the LDC debt. even after the substantial provisions. The conclusion seems to be 
Table 10. Primary capital as a percentage of total assets (year end).

\begin{tabular}{|c|c|c|c|c|c|c|c|}
\hline & 80 & 81 & 82 & 83 & 84 & 85 & 86 \\
\hline $\begin{array}{l}\text { Citicorp } \\
\text { BankAmerica } \\
\text { Chase Manhattan } \\
\text { Manufacturer's H. } \\
\text { J.P. Morgan } \\
\text { Chemical } \\
\text { Security Pacific } \\
\text { First Interstate } \\
\text { Bankers Trust } \\
\text { First Chicago }\end{array}$ & $\begin{array}{r}3.8 \\
4 \\
3.8 \\
3.6 \\
4.7 \\
3.7 \\
4.9 \\
5.1 \\
3.5 \\
4.7\end{array}$ & $\begin{array}{l}4.1 \\
3.9 \\
4.2 \\
3.8 \\
5.1 \\
4 \\
4.7 \\
5.1 \\
4.1 \\
4.3\end{array}$ & $\begin{array}{l}4.2 \\
4.3 \\
4.8 \\
4.6 \\
5.6 \\
5 \\
4.8 \\
5.1 \\
4.5 \\
4.7\end{array}$ & $\begin{array}{l}4.9 \\
5.1 \\
5.4 \\
5 \\
6.9 \\
5.5 \\
5.3 \\
5.8 \\
5.6 \\
5.6\end{array}$ & $\begin{array}{l}5.9 \\
5.8 \\
6.4 \\
5.7 \\
7 \\
6.3 \\
5.8 \\
6.1 \\
6.2 \\
6.1\end{array}$ & $\begin{array}{l}6.2 \\
6.1 \\
6.9 \\
6.3 \\
8 \\
7 \\
6.4 \\
6.2 \\
6.4 \\
7.2\end{array}$ & $\begin{array}{l}6.8 \\
6.9 \\
7.0 \\
7.2 \\
8.3 \\
7.2 \\
6.4 \\
6.1 \\
6.5 \\
8.3\end{array}$ \\
\hline & $-\cdots$ & & & & & & \\
\hline Average & 4.2 & 4.3 & 4.8 & 5.5 & 6.1 & 6.7 & 7.1 \\
\hline
\end{tabular}

Source: Review of Bankperformance, Salomon Brothers, varlous editions. 
Table 11. Shareholders' equity as a percentage of total assets (year end).

81

82

3.6

3.4

3.9

BankAmerica

Chase Manhattan

Manufacturer's H.

J.P. Morgan

Chemical NY

Securlty Pacific

First Interstate

Bankers Trust NY

First Chicago

Average

3.7

3.7

3.9

3.2

4.5

3.5

4.0

4.3

3.9

3.7

3.8

4.0
83

4.6

4.6

4.9

5.0

3.5

Sources: New York Times, July 2, 1987; Revlew of Bankperformance, various Editions, Salomon Brothers. 
that the regulators have not succeeded in raising the ratio of shareholder's equity to total assets by much at all in the 1980s. The regulatory laxness, 1,e. "business as usual" attitude, certainly contributed to the fallure of the banks to make a greater advance in rebuilding their equity base. It was clear from the beginning of the debt crisis that at least some of the interest earnings on the LDC debt should have been regarded as fictitious, particularly when leading debtors required new involuntary loans to meet interest payments on existing debts. Prudent regulators might have required that the banks build up capital in part by reducing dividend payouts. This did not in fact occur. The major banks malntalned dividend payout ratios since 1982 as if the debt crisis had not occurred, as is evident in Table 12. Bank of America was a particularly flagrant case of this behavior. Even when earnings were falling because of bad domestic loans, not to mention bad foreign loans, Bank of America continued to pay signiflcant dividends, leading to a sharp rise in the ratio of dividends to 1ncome, Of course, Bank of America is now fighting for its survival.

Our conclusion on the slow pace at which the banks have rebullt capital must be tempered to the extent that other assets of the banks are undervalued on the books relative to true market values. Indeed, we shall soon see evidence in the next section that the market values of many of the large banks were at or above their book values as of the sumer of 1987, despite the clear evidence that the market values of their LDC claims were far below their book values. This suggests that other assets were being undervalued on the books. 
Table 12. Dividend pay-out ratio's for ten banks with large LDC exposure.

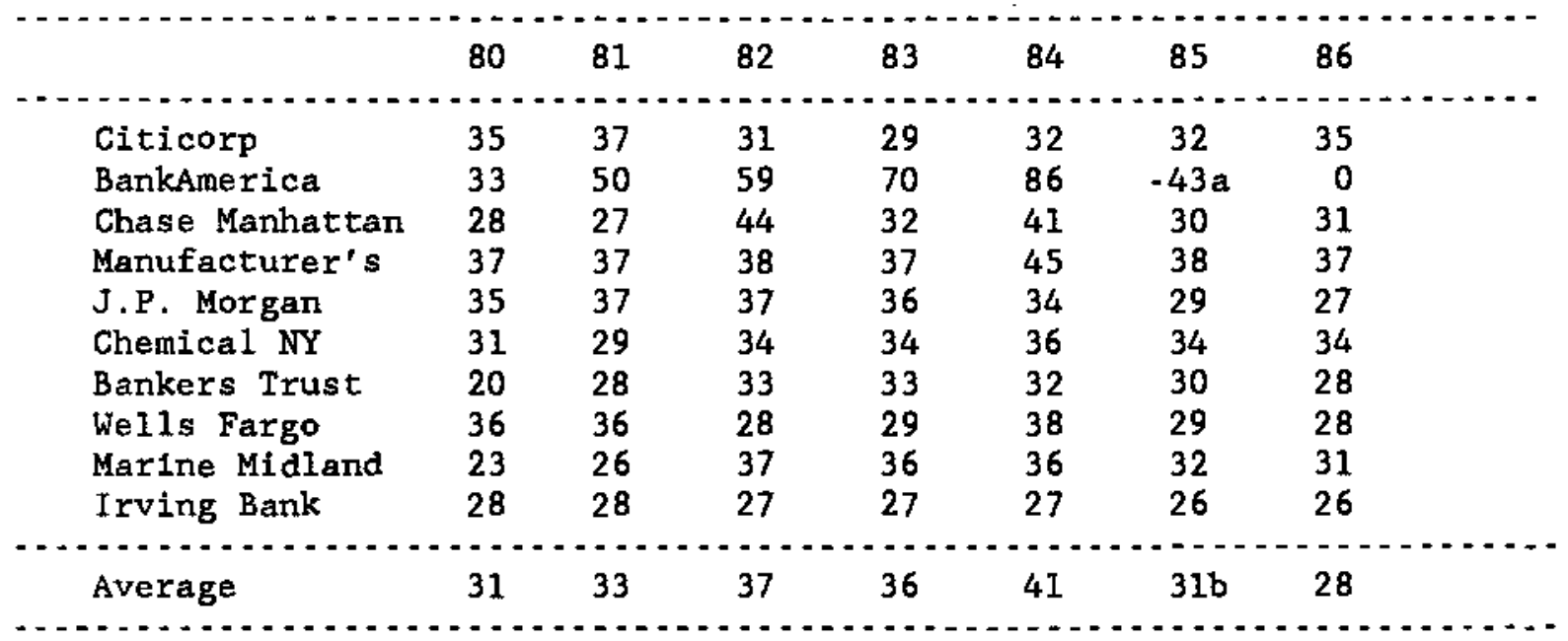

a. BankAmerica paid a dividend of $\$ 1.16$ per common share despite losses of $\$ 2.68$ per share.

b. Excluding BankAmerica.

Source: Review of Bankperformance, Salomon Brothers, various editions. 
We have attempted to create an equity-asset ratio based solely on market values rather than book values, by calculating the market value of overall assets of the bank as equal to the market value of overall assets of the bank as equal to the market value of bank equity plus the book value of bank liabilities (we assume that the bank's liabilities, which are mostly short-term fixed-income liabilities, have a market value equal to book value). We then take the ratio of the market value of equity to the (constructed) market value of assets. We found that on average for the large 10 banks, the ratio of equity (at market value) to assets rose from 3.2 percent in 1983, and 3.6 per cent in 1984, to 5.5 percent in June 1987, suggesting some real increase in capital adequacy. On the other hand, the sharp decline in the stock market in October 1987, after the completion of this analysis, has probably pushed the market-based ratio of equity to assets back down sharply, close to the levels of 1984.

There would be one important practical implication for LDC debt if the banks' non-LDC claims are carried on the books at below market value. As the losses on the LDC assets are realized, e.g. by sales of debt in the secondary market, the banks will be able to cushion the effect on their overall capital by selling off other assets that are undervalued on the books, and taking the capital gains. Citicorp has begun to adopt this strategy in the Fall of 1987, by selling a part of its real estate equity at a significant capital gain, in order to offset the reported losses on its LDC portfolio.

Pending Regulatory Decisions 
Two important regulatory matters are now pending. The first, and specific matter, is the question of future accounting treatment of the Brazilian debt. The federal bank regulators can require the banks to make allocated provisions for loans to foreign governments under the system of Allocated Reserve Transfer Risks (ATRRs) established in the 1983 International Lending Supervision Act. In this system, an inter-agency committee of the Federal Reserve Board, the Federal Deposit Insurance Corporation, and the Comptroller of the Currency, can declare the loan to a country to be value-impaired, and $c$ mpel a writedown of the assets (technically, an allocated reserve is created). Generally, for loans to be declared value impaired they must meet more than one of four conditions: (1) interest is more than 180 days overdue; (2) the country has no IMF program and no prospect of negotiating one; (3) the country has not met its rescheduling terms for a year; and (4) the country does not exhibit any definite prospect for an orderly restoration of debt servicing in the near future. ${ }^{17}$ The final decision is at the discretion of the bank regulators. Typically, the required writeoff is 10 percent in the first year, and 15 percent in the second year and each succeeding year that the loans are deemed to be value impaired. The ATRR has so far been applied only to a few smaller debtor countries, specifically Bolivia, Nicaragua, Peru, Poland, Sudan, and Zaire.

In the case of Brazil, the suspension of interest payments on the soverelgn debt was announced on February 20, 1987. On April 2, somewhat less than sixty days after the suspension, several banks 
announced that they were placing Brazilian loans on a nonaccrual basis. As of August 20, 1987, the loans were in suspension of interest for 180 days. The Interagency taskforce is scheduled to meet on October 26, 1987, to decide whether the Brazllian debt should be declared value impalred. This will be a discretionary decision. An partial payment of Interest by Brazll before October 26, for Instance, may be enough to forestall a declaration that the loan is "value Impalred" .

The second, a much more general matter is the question of future capital adequacy regulations. The Federal Reserve Board and the Bank of England have recently agreed to attempt to harmonize their accounting treatment for the supervision of capital adequacy. The detalls of the agreement have not been fully worked out, and are In any event not yet public. It is presumed, however, that the new system will Involve a weighting of assets by quality in order to arrive at a more refined measure of the capital of the bank.

There are several areas in which existing accounting practices differ markedly in the two countrles. Presently, for instance, the Bank of England requires that provisions of U.K. banks against LDC debts must be allocated by country. The provisions are charged against the capital base of the bank, and also may be charged against current Income for tax purposes. Recently, moreover, the Bank of England has Instituted a scoring system by which the U.K. banks must evaluate their risks on all LDC loans, and thereby decide upon reserve levels. 
Latin American exposure and the market valuation of commercial banks

The regulators and accounts have so far operated on the presumption that claims on the LDCs are worth their full face value, despite the overwhelming evidence to the contrary. In this section we investigate whether the stock markets have seen through the accounting veil, and written down the value of banks with heavy exposures in the problem debtor countries. The evidence suggests that a significant writedown has in fact occurred, though 1ts precise magnitude is open to some question.

One of the problems in getting a precise estimate of the stock market valuation of the LDC claims is that of limfted data: banks are only required to report exposures in the LDCs when total loans to a country exceed 1 percent of total assets. Therefore, whlle we know quite $a$ bit about the exposures of Individual banks in Argentina, Braz11, Mexico, and Venezuela, (hereafter ABMV) we know very little about the holdings by Individual banks of clatms on the other problem countries (which account for about 30 percent of exposure as shown in the data in Table 1).

An Initial look at bank share prices supports the vlew that the markets have reacted to the bad news of recent years. Table 13 shows a comparison of ten banks with the heaviest recorded exposure in ABVM (relative to book value of shareholder's equity) to ten banks with no exposure. For the heavily exposed banks, the average exposure Is 130 percent of book value. At the end of 1986, these banks had an average ratio of their stock market value to their book value of 1.0 , 
Table 13. A Comparison of Banks with Large versus No Exposure in Latin America.

\begin{tabular}{|c|c|c|c|c|c|}
\hline Bank & $\mathrm{EXP} / \mathrm{BV}$ & $\mathrm{MV} / \mathrm{BV}$ & $P / E$ & $\mathrm{E} / \mathrm{BV}$ & $\mathrm{DIV} / \mathrm{E}$ \\
\hline \multicolumn{6}{|c|}{ Large Exposure } \\
\hline Citicorp & 1.2 & 1.1 & 6.6 & 0.12 & 0.38 \\
\hline BankAmerica & 1.7 & 0.5 & 5.4 & -0.17 & 0 \\
\hline Chase Manhattan & 1.4 & 0.8 & 5.1 & 0.12 & 0.33 \\
\hline Manufacturer's H. & 1.8 & 0.6 & 4.7 & 0.12 & 0.37 \\
\hline J.P Morgan & 0.9 & 1.8 & 9.6 & 0.17 & 0.29 \\
\hline Chemical NY & 1.4 & 0.8 & 5.4 & 0.13 & 0.37 \\
\hline Wells Fargo & 0.7 & 1.6 & 9.3 & 0.14 & 0.31 \\
\hline Marine Midland & 1.1 & 0.8 & 6.8 & 0.11 & 0.28 \\
\hline Irving Bank Corp. & 1.4 & 0.8 & 6.1 & 0.12 & 0.33 \\
\hline Average & 1.3 & 1.0 & 6.6 & 0.10 & 0.30 \\
\hline
\end{tabular}

No Exposure a/

Midlantic Banks Inc. 0. Michigan National

Meridian Bancorp.

0.0

1.6

9.5

0.17

0.27

BayBanks

0.0

1.3

8.5

0.11

0.34

First Security-Utah

0.0

1.2

10.0

0.14

0.43

State Street Boston

0.0

1.4

9.0

0.13

0.38

Commerce Bankshares

0.0

13.0

0.01

2.68

Dominion Bankshares

Amsouth Bankcorp.

15.1

0.16

0.22

0.0

1.1

9.2

0.11

0.29

0.0

1.5

9.3

0.15

0.36

0.0

1.6

9.2

0.16

0.37

Average

0.0

1.5

10.3

0.13

0.59

a) No recorded exposure (banks must report LDC exposure only when - exposure exceeds one percent of total assets).

Note. EXP/BV - exposure to Argentina, Brazil, Mexico and Venezuala over bank book value for 1986 .

$\mathrm{MV} / \mathrm{BV}=$ stock price over per share book value as of mid-1987. P/E - price earnings ratio expected for 1987 prior to recent major additions to loan loss reserves.

E/BV - per share earnings over book value for 1986

$\mathrm{DIV} / \mathrm{E}=$ current annual dividend rate for mid-1987 over 1986 earnings.

Sources: Keefe Bruyette \& Woods Inc.; A Review of Bankperformance, 1987, Salomon Brothers. 
in comparison with a ratio of 1.5 for the banks with zero exposure. Similarly, the heavily exposed banks had a price-earnings ratio of 6.6, compared with a price earnings ratio of 10.3 for the banks with zero exposure. This shows that the difference in market value is not a function of the difference in current earnings, but rather the price which the market is assigning to those current earnings. Put another way, the market is casting doubt on the future earnings of the heavily exposed banks by capttalizing those banks at a lower price-earnings.

The last two columns highlight two considerations discussed earlier. Leaving aside Bank of Amerlca, with its extremely weak domestic portfolio, the heavily exposed banks had a rate of earnings In 2986 relative to book value that is comparable to that of the banks with zero exposure. Once again, through the end of 1986 (before the loan loss reserves in 1987 and the Brazillan moratorium) the debt crisis posed a problem of future earnings, not current earnings. The last column highlights the fact that the dividend payout ratlos of the heavily exposed banks have not been systematically lower that the dividend payout ratios of the Iightly exposed banks (note, however, the two outllers: Bank of America, which suspended its dividend in 1986; and First-Security Utah, which paid dividends in excess of current earnings in 1986).

More generally, bank analysts concur that the current market discounts are in line with, or even greater than, the quoted prices on the secondary market. ${ }^{18}$ This view also helps to explain the market's reaction to Citlcorp's unanticipated announcement of $\$ 3$ billion in increased loan loss reserves in mid-May. The markets reacted to the 
prospect of billions of dollars of newly announced losses by raising citicorp prices by more than 10 percent in the week of the announcement! Clearly, the news from the announcement was not the bad news of losses, but the good new of a management strategy to confront the losses agressively. One investment analyst was quoted as explaining "There was a huge sigh of relief that the bad news was out". 19

The remainder of this section presents regression results that provide a somewhat more precise estimate of the market valuation of LDC loans to the banks, as implicit in the banks' stock prices. Four parallel approaches are taken that yield largely consistent results. The first approach starts from the observation that the market value of a bank's assets should equal the market value of the firm's equity plus its liabilities. As the market value of a bank's equity is observed in the stock market, and the market value of a bank's liabilities can be reasonably assumed to be very close to book value, we can get a measure of the market value of a bank's assets. Then, by comparing the market and book values of bank assets on a cross. sectional basis, we can estimate the market value of of LDC claims held by the varfous banks.

The second and third approaches relate the banks' price- earnings ratio's and the returns to holding bank stocks to measures of LDC exposure. The final approach studies the movement of bank share prices In response to important LDC exposure- related news.

(a) Valuing bank assets 
The market values of the securities on the two sides of bank balance sheets should be equal. Thus the market value of a bank's assets should equal the market value of its combined shareholders' equity and liabilities. As a bank's liabilities are primarily short-term liabilities such as customers' bank deposits and short-term CDs, we can assume that the market value of a bank's liabilities are valued close to book value. Also, we assume that the market value of a bank's preferred equity, which for most banks is less than 10 per cent of shareholders' equity, is equal to book value. ${ }^{20}$

Using $\theta_{1}$ to denote the market value of one dollar of claim on the LDCs (i.e. $1-\theta_{1}$ is the market discount on the LDC claim) and $\theta_{2}$ to denote the market value of one dollar of other assets, we use the following relationship:

$$
\mathrm{MVc}+\mathrm{BV}_{\mathrm{p}}+\mathrm{BVl}=\theta_{1} \mathrm{Aldc}+\theta_{2} \text { Aother }
$$

where

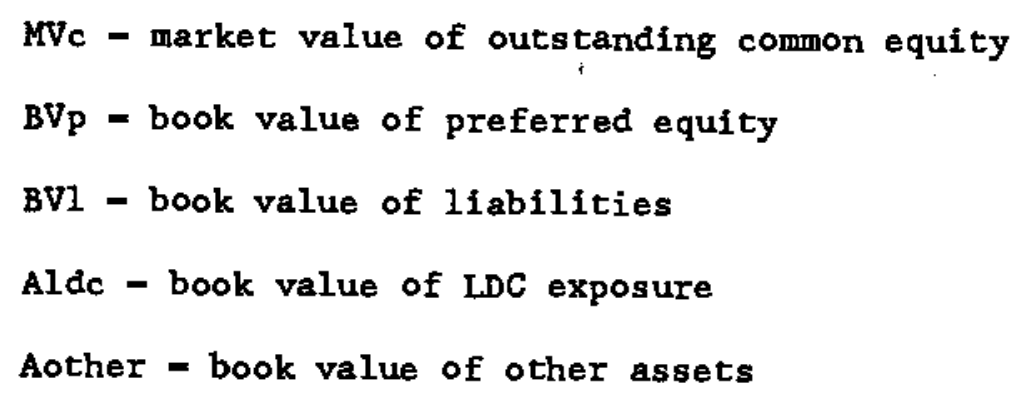

Using Atotal to denote total assets, we can substitute Atotal - 
Aldc for Aother, and divide by Atotal to get the relationship:

$$
\begin{gathered}
\mathrm{MVc}+\mathrm{BV}_{\mathrm{p}}+\mathrm{BVl} \\
\text { Atotal }
\end{gathered}
$$

$$
\begin{aligned}
& \text { where } \alpha=\theta_{2} \\
& \quad \beta=\theta_{1}-\theta_{2}
\end{aligned}
$$

The above equation is estimated for a cross section of banks for each of the years 1982 through 1986 and for June 1987. The regression for June 1987 uses the end-of-1986 data for exposure and asset values, but uses the June 1987 stock prices to compute the market value of assets. Because the banks are required to disclose LDC exposure to individual countries only if exposure is in excess of one percent of assets, we can obtain comprehensive exposure data only for the major borrower countries. In particular, Aldc is limited to include the exposure to Argentina, Brazil, Chile, Mexico, and Venezuela. This introduces a bias in the point estimate of $\beta$ which we discuss below.

Table 14 reports the estimation results. Note that for each of the years 1983 through June 1987 the estimated value of - has a negative value and is statistically significant. As the coefficient is equal to the difference between the market values of other assets and LDC loans, it is clear that a dollar on the books to the LDCs contributes less to bank market value than a dollar lent elsewhere. As noted, the exposure variable only covers part (about three fourths) of LDC exposure. The omission of other LDC loans biases the coefficient upward in absolute value to the extent that banks that are heavily exposed in ABVM are also heavily exposed elsewhere, and to the 
Table 14. Asset value regression results.

\begin{tabular}{|c|c|c|c|c|}
\hline Year & Gonstant & EXP/ASSETS & R2 & $\mathbf{N}$ \\
\hline 87 (June) & $\begin{array}{r}1.026 \\
(122.91)\end{array}$ & $\begin{array}{l}-0.576 \\
(-2.61)\end{array}$ & 0.18 & 33 \\
\hline 86 & $\begin{array}{r}1.020 \\
(116.95)\end{array}$ & $\begin{array}{r}-0.610 \\
(-2.65)\end{array}$ & 0.18 & 33 \\
\hline 85 & $\begin{array}{r}1.008 \\
(294.87)\end{array}$ & $\begin{array}{l}-0.456 \\
(-4.43)\end{array}$ & 0.30 & 48 \\
\hline 84 & $\begin{array}{r}0.994 \\
(364.26)\end{array}$ & $\begin{array}{r}-0.223 \\
(-3.10)\end{array}$ & 0.17 & 50 \\
\hline 83 & $\begin{array}{r}0.992 \\
(455.01)\end{array}$ & $\begin{array}{r}-0.174 \\
(-3.02)\end{array}$ & 0.16 & 50 \\
\hline 82 & $\begin{array}{r}0.980 \\
(432.99)\end{array}$ & $\begin{array}{r}0.049 \\
(0.81)\end{array}$ & 0.01 & 49 \\
\hline
\end{tabular}

Note. The dependent variable is the sum of the market value of common stock plus the book values of preferred stock and liabilities. EXP/ASSETS denotes exposure to Argentina, Brazil, Chile, Mexico and Venezuela over book value of assets. Parentheses indicate t-statistics. 
extent that other LDC assets are also selling at a discount. Thus we should adjust the estimated coefficlent downward.

If a bank's exposure to ABVM were perfectly correlated with other LDC exposure, if the markets (unlike us!) knew about the remaining exposure, and if the rest of the LDC sold at the same discount as ABVM, then an unbiased estimate of $\beta$ for all LDC debt would be approximately three fourths of the actual estimate, since ABVM accounts for about three-fourths of the total bank exposure. As there is not perfect correlation nor perfect knowledge of the rest of the banks' LDC portfolios, an adjustment factor of something greater than thrae-fourths is appropriate. We choose to decrease the point estimate by a factor of 0.8 to get our preferred point estimate of the value of the LDC debt.

Then, using the estimates of Table 13 we find the following implicit market prices per $\$ 100$ of face value of claim:

$\begin{array}{lr}1987 \text { (June) } & 57 \\ 1986 & 53 \\ 1985 & 64 \\ 1984 & 82 \\ 1983 & 85 \\ 1982 & 102\end{array}$

The serles shows that the market started discounting the LDC debt not in 1982 when Mexico first announced its Inability to service its forelgn debt, but in 1983. Ever since 1983 there has been 
a trend towards greater discounts, a finding consistent with the trend in secondary market prices observed in Table 4.

\section{(b) Bank excess return equations}

These results are supported by the results of a set of bank stock excess return regressions represented in Table 15 . Excess returns for a particular bank in a particular period are measured as the difference between the holding-perlod yield for the bank (capital gains plus dividend yleld) and the holding-perlod yield of the Standard \& Poor 500 stock market index multiplied by the individual bank's beta coefficient. The regressions relate excess return to exposure to Argentina, Brazil, Chile, Mexico, and Venezuela divided by bank book value. The Table first reports an excess return equation spanning the entire 1982 - June 1987 period, and also a set of yearly regressions. The 5-year excess return regression and alternative regressions for 1986 and January- June 1987 include a dummy variables that is set equal to 1 for banks located in Texas. Th1s dummy is meant to capture the effects of the ofl slump on the profitability of Texas banks.

The 5-year regression indicates that a bank with a exposure to book value ratio of one would have suffered a negative excess return of 65 percent. From the yearly regressions, we find a statistically significant effect of exposure only for 1983. However, the estimated coefficlents are negative for all years except 1986. By summing the coefficlent estimates for each of the years, we can get an alternative 
Table 15. Bank stock excess returns.

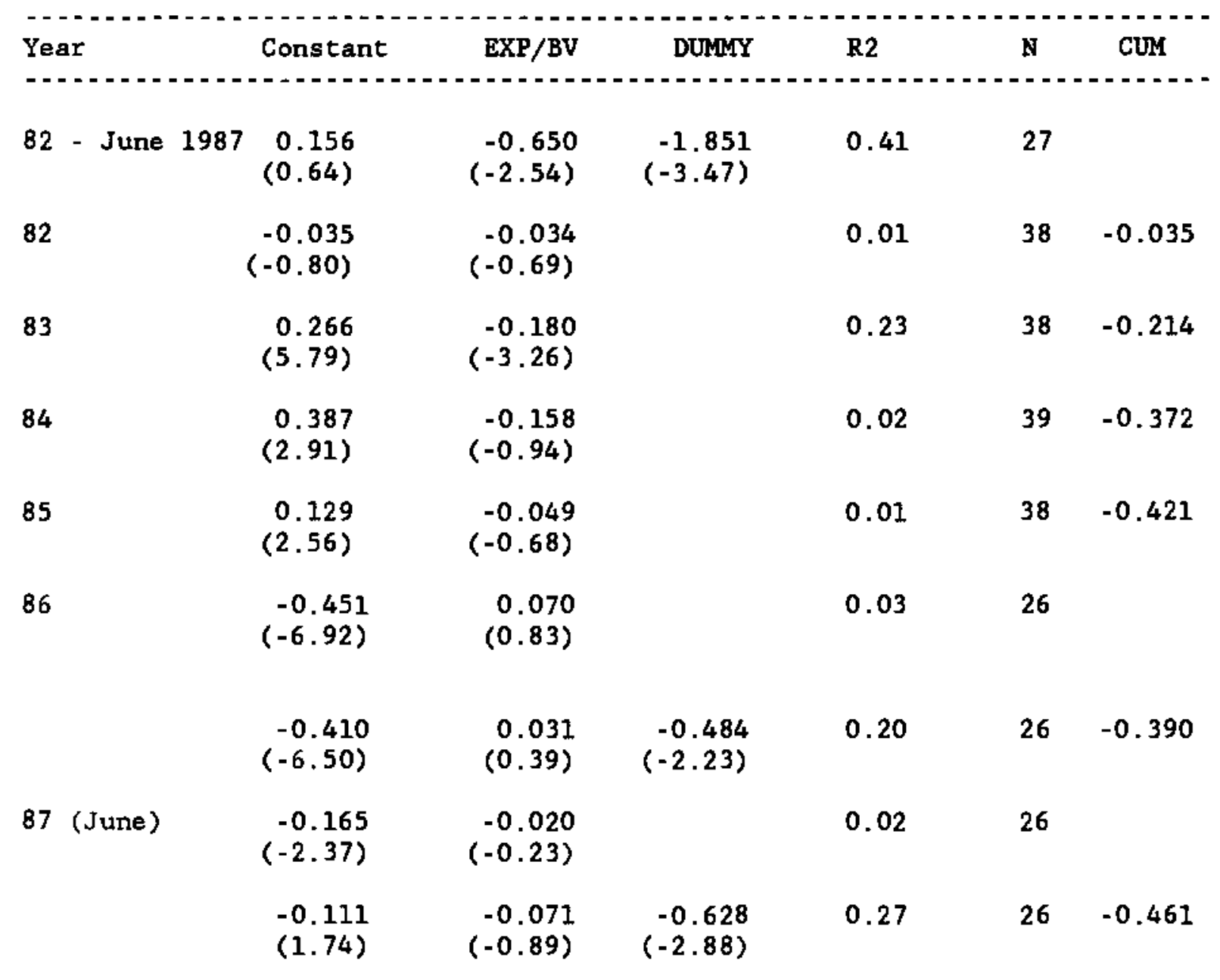

Note. The dependent varlable is the stock holding rate of return (computed from stock price change and dividend) minus the Standard $\&$ Poor 500 holding rate times the bank beta coefficient. $\mathrm{EXP} / \mathrm{BV}=$ Exposure to Argentina, Braz1l, Chile, Mexico, and Venezuela over bank book value. For the 5-year regression exposure for 1984 was chosen.

DUMMY - dummy equal to one for a Texas bank (F1rst City Bank). 
estimate of the cumulative negative excess return (CUM) associated with LDC exposure, as shown in the last column of Table 15. On this basis, by June 1987 the cumulative excess return was -46 per cent for a bank with a exposure-to-book value ratio of one.

\section{(c) Price-earnings ratios}

As a third way to test the relationship between stock prices and LDC exposure, we regress the banks price-earnings ratios on the ratio of ABVM exposure to book value. As the sovereign borrowers have been current in their interest payments, with the major exception of Argentina during 1984, earnings assoclated with Latin exposure have not suffered considerably. Low expectations about future debt servicing however, should be expected to depress the price-earnings ratios. Table 16 shows that the estimated coefficient on the exposure variable is indeed negative for all six years, and it is statistically significant after 1984 .

The relative value of the constant term and the coefficient on the exposure variable provides an Indication of the discount on LDC exposure relative to other assets. A bank with no exposure has a price-earnings ratio given by the constant term. A bank with the same book value but with assets that are only LDC claims (with an exposure-capital ratio of 1.0 ) has a price earnings ratio equal to the constant minus the coefficient on the exposure variable. Assuming that current earnings are proportional to book value, regardless of the distribution between LDC claims and other assets, we can divide 
Table 16. Price earnings ratio's and Latin exposure.

\begin{tabular}{|c|c|c|c|c|}
\hline Year & Constant & EXP/BV & R2 & $\mathbf{N}$ \\
\hline 87 (June) & $\begin{array}{r}10.628 \\
(13.74)\end{array}$ & $\begin{array}{l}-3.771 \\
(-3.71)\end{array}$ & 0.29 & 36 \\
\hline 86 & $\begin{array}{r}9.703 \\
(10.34)\end{array}$ & $\begin{array}{r}-3.632 \\
(-2.95)\end{array}$ & 0.20 & 36 \\
\hline 85 & $\begin{array}{r}10.264 \\
(20.31)\end{array}$ & $\begin{array}{r}-4.138 \\
(-5.63)\end{array}$ & 0.41 & 48 \\
\hline 84 & $\begin{array}{l}14.674 \\
(4.62)\end{array}$ & $\begin{array}{l}-5.242 \\
(-1.31)\end{array}$ & 0.04 & 48 \\
\hline 83 & $\begin{array}{r}7.662 \\
(13.85)\end{array}$ & $\begin{array}{r}-1.443 \\
(-2.10)\end{array}$ & 0.09 & 49 \\
\hline 82 & $\begin{array}{r}5.839 \\
(28.81)\end{array}$ & $\begin{array}{c}-0.210 \\
(-0.91)\end{array}$ & 0.02 & 49 \\
\hline
\end{tabular}


the two price- earnings ratios to get the market price of the LDC claims relative to the price other assets (for the same size book value of each type of asset). Assuming that other assets have a price of 1.0 , and that the coefficient on the exposure vartable is overstated by a factor of (1/0.8) for reasons described earlier, we get the following alternative estimates of the LDC prices:

$\begin{array}{ll}1987 \text { (June) } & 72 \\ 1986 & 70 \\ 1985 & 68 \\ 1984 & 71 \\ 1983 & 85 \\ 1982 & 97\end{array}$

These estimates are broadly consistent with the estimates from the asset value approach, though the Implied discounts are somewhat smaller. Note that if the measured current earnings on the LDC assets are smaller than the earnings on the alternative assets per dollar of book value, then our procedures in this section would understate the discount of on the LDC claims.

(d) Event studies

The section concludes with a serfes of event studies. Here we look at the movements of bank prices over a perfod of a day or a few days, following the some Important news related to the value of LDC claims. This kind of evidence can help to bolster the view that the 
markets react sensitively to news concerning the value of the LDC clatms .

We choose four events: (1) the announcement of the Austral plan In Argentina; (2) the announcement of the Cruzado plan In Braz11; (3) the announcement by Brazil of a unilateral suspension of interest servicing in February 1987; and (4) the announcement by Citicorp of the increase in loan loss reserves on Latin American exposure. On Friday night of June 14, 1985 President Alfonsin of Argentina announced an accord with the IMF on an imaginative stabilization program and monetary reform. Simultaneously, the U.S. Treasury in Washington announced that it had succeeded in assembling a multilateral 480 million dollar short-term loan for Argentina to assist it with its immediated loan obligations. Even though on the following Monday the Wall Street Journal printed an article with the heading "Argentina's latest austerity program is greeted with skepticism by analysts," bank stock prices did well that day. The results of a regression of bank stock returns on Monday on the ratio of Argentine exposure to bank book value is shown in the first regression in Table 17. According to the equation, Argentine assets as valued in the stock market rose in value by approximately $\$ 12.0$ per $\$ 100$ of claims (the coefficient 0.097 is scaled up by the ratio of $\mathrm{MV} / \mathrm{BV}$ to get 0.12 .

On Monday March 3 1986, Brazil announced a similar austerity program that included an agreement with forelgn private creditors reached the previous Saturday. The agreement called for a reduction in interest payments of $\$ 150$ million in 1985 and 1986 on $\$ 1.5$ billion 
Table 17. Event studies of the returns to bank stocks.

Announcement of Austral Plan (June 18, 1985)

\begin{tabular}{|c|c|c|c|c|c|}
\hline (1) & Constant & ARG/BV & & R2 & $\mathrm{N}$ \\
\hline & $\begin{array}{l}-0.018 \\
(-3.08)\end{array}$ & $\begin{array}{r}0.097 \\
(2.77)\end{array}$ & & 0.31 & 19 \\
\hline & \multicolumn{5}{|c|}{$\begin{array}{l}\text { Annoucement of Cruzado Plan } \\
\text { (March 3, 1986) }\end{array}$} \\
\hline (2) & Constant & PUBRA/BV & PRBRA/BV & R2 & $\mathrm{N}$ \\
\hline & $\begin{array}{r}0.009 \\
(0.93)\end{array}$ & $\begin{array}{l}-0.079 \\
(-2.02)\end{array}$ & $\begin{array}{l}-0.026 \\
(-0.91)\end{array}$ & 0.23 & 19 \\
\hline
\end{tabular}

Annoucement of Brazil Suspension

(February 20, 1987)

\begin{tabular}{|c|c|c|c|}
\hline (3) Constant & BRA/BV & R2 & N \\
\hline $\begin{array}{r}0.005 \\
(0.59)\end{array}$ & $\begin{array}{r}-0.030 \\
(-1.28)\end{array}$ & 0.08 & 21 \\
\hline
\end{tabular}

(February 19-26, 1987)

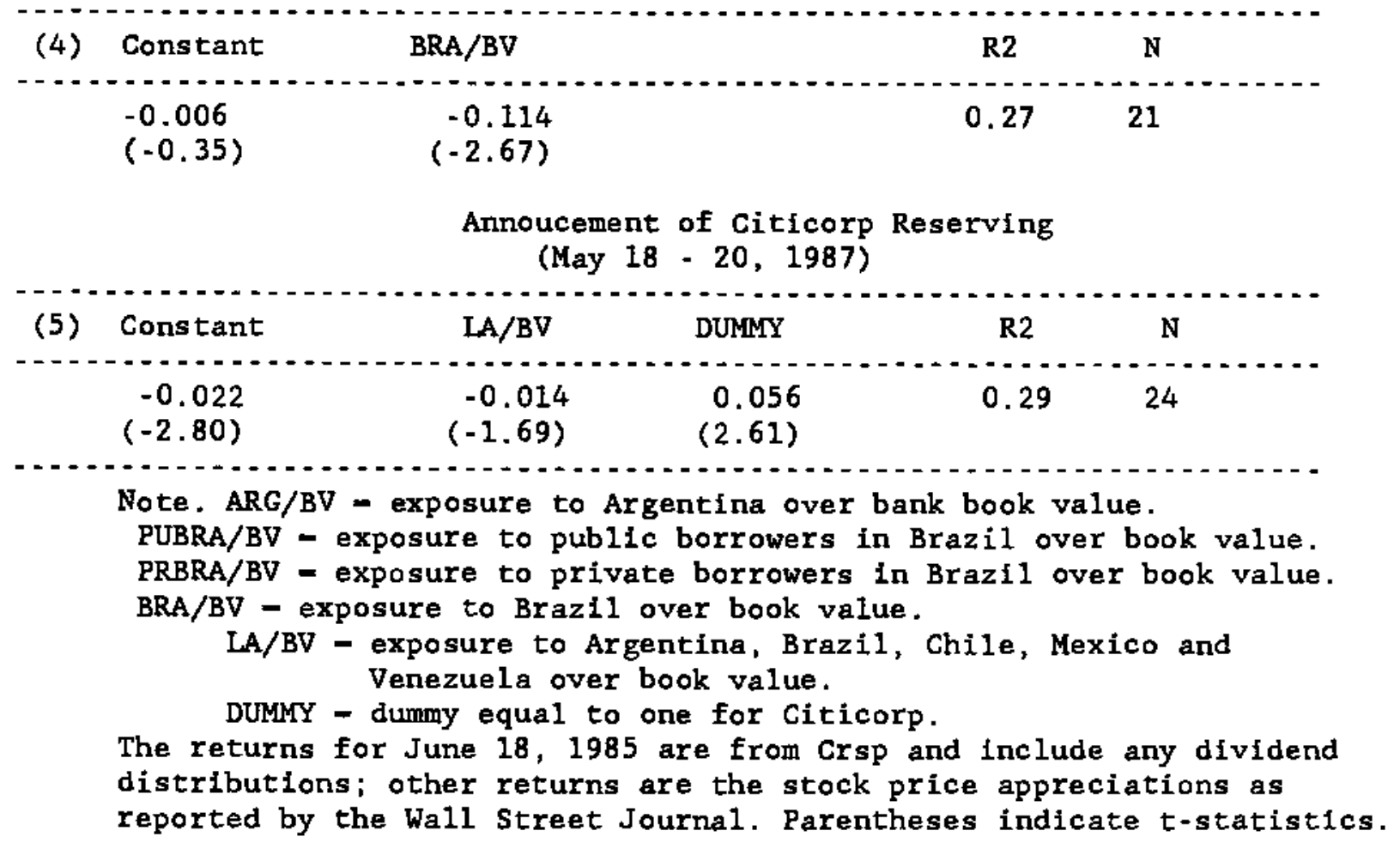


of debt and a refinancing of $\$ 6$ billion that matured in 1985. The second regression of Table 17 shows that the combination of the rescheduling negotations and the new program was disappointing to bank stock investors, as bank stock returns on that day are significantly negatively related to the banks' Brazilian claims. Each $\$ 100$ of Brazilian public claims is estimated to have declined in value by $\$$ 8.1 , and each $\$ 100$ of private claims by $\$ 2.7$.

Almost a year later, on Friday, February 20, 1987, the Brazilian Minister of Finance, Mr. Dilson Funaro, sent a telex to Brazil's 700 creditor banks announcing a moratorium of interest payments on medium-term and long-term commercial bank debt. The Wall Street Journal commented that international bankers had grown used to debt alarms and that they were taking Brazil's action in stride. Indeed, the third regression in Table 17 shows that on February 20 bank stock returns were only weakly negatively related to the ratio of exposure to Brazil to book value. However, during the following week, bank stocks tumbled as Brazil took further steps that indicated its resolve, On Monday, February 23, Chase Manhattan Bank, Chemical Bank and Citicorp each lost more than 5 per cent of their stock values. On Wednesday, February 25 Brazil tightened its policy by telling its banks not to repay foreign creditors seeking to recall short-term credit. The fourth regression in Table 17, which relates the return on bank stocks between February 20 and February 26 to the exposure to book value ratio shows that the cumulative effect during the week of Brazil's interest moratorium on bank stock prices is significant and highly negative. 
The final event relates to the announcement by Citicorp on May 19, 1987 that it would add $\$ 3$ billion to its loan loss reserves in anticipation of future write-downs of Latin loans. The fifth regression in Table 17 relates Latin exposure over book value to stock price movements between the day before and the day after Citicorp's announcement. The added dummy variable is for Citicorp itself. The regression shows that Citicorp stock went up by 4 percent, while other bank's stocks went down slightly (and without statistical significance).

Stock Market Values and Debt Renegotiation

The evidence on the market value of LDC debt has a crucial implication for future negotiations between debtors and creditors, as well as for the policy options of the official community. The commercial banks should be willing to trade their LDC debt of a given face value for a safer asset with a lower face value (we will term such a trade a "debt conversion"). In the simplest case (and for the moment ignoring tax and accounting complications), if the stock market values the debt at $\$ 60$ per $\$ 100$ of face value, then the bank's shareholders will benefit if the bank sells each $\$ 100$ of debt for cash at any price in excess of $\$ 60$. Of course, the swap need not be with cash; any marketable security, such as a bond or an equity claim, with a market value in excess of $\$ 60$ will do. Such a debt conversion could result from direct negotiations between creditors and debtors, or possibly through the policy actions of the official community as illustrated below. Several benefits are likely to result 
from debt conversion schemes that convert the current debt, now priced at a discount, into cash, or Into new claims at a reduced face value (but which are then priced near the new lower face value). We shall suggest that there is a strong case for pollcymakers to take positive actions to support such debt conversions.

Debt Conversions through Bilateral Debtor-Creditor Arrangements

There are many ways that debt conversions may be arranged directly between debtors and creditors. The simplest case, with a long historical tradition, is for the debtor to enter the secondary market for Its debt, and repurchase some or all of the debt for cash at a deep discount. As Lindert and Morton, Jorgensen and Sachs, and others have recorded, such repurchases of heavily discounted bonds took place in the 1930s._1/ There are, however, several problems with a widespread use of debt repurchases.

A first problem is contractual. In most of the existing debt contracts with the commercial banks, there is a "sharing provision", which requires that all payments by the debtor to the creditors must be equally shared by the participating banks. Technically, a debt repurchase violates this clause, since the bank that selis its claim gets a lump sum payment that is not recelved by the other banks. The creditors and debtor can negotlate a waiver to eliminate the sharing provision, though such a walver generally requires the nearly unanimous consent of the bank creditors. A waiver has been negotlated during 1987 in the case of Bolfvia, under the restrictive condition that Bolivia will repurchase lts debt only with funds that 
have been donated to Bollvia by forelgn governments expressly for the purpose of debt repurchases.

A second problem with direct repurchases involves the regulatory environment facing the banks. The main problem is that when a bank sells its claim for cash, it must record a capital loss on the transactions, equal to the difference of the face value of the clain and the purchase price. This capital loss reduces the book value of bank capital, and may trigger regulatory problems by reducing the ratio of primary capital (measured at book value) to assets. Suppose the bank sells a $\$ 100 \mathrm{claim}$, valued in the secondary market at $\$ 60$, for $\$ 65$. At market prices, it would enjoy a $\$ 5$ gain. In book value, however, it would have to record a $\$ 35$ loss. We have seen that, in general, the stock market responds to the change in market valuation, and not in book valuation. However, if the decline in book value is large enough to cause the bank to come close to or fall below regulatory limits on capital-to-asset ratios (measured at book values), then the freedom of manuever of the bank might be jeopardized.

Clearly, the regulatory environment imposes a bias against debt sales, since it now allows an asset worth $\$ 60$ to be held on the books at $\$ 100$ until that asset is actually sold at its reduced value. One possible response of the regulators could be to ease the regulations to allow the capital loss from debt sales to be amortized over a period of several years (such an approach was recently introduced for some kinds of bad farm loans.) Other "tricks" are also available, that disguise the debt repurchase in such a way that an immediate 
writedown is avoided. 21

A related regulatory problem is that if a bank sells some of its claim on a country at a discount, then the regulators and the bank's own auditors might force it to write down the rest of the its claims on the debtor. The regulatory treatment here remains murky. That murkiness has apparently prevented many banks from selling off small portions of their exposure in a particular country, because of the risk that the resulting capital losses would be imposed over their remaining claims on the country as well.

A third problem with repurchases is that the debtor country generally does not have the cash available to make a major repurchase of its debt. If the required large amount of cash were available, the debt itself would likely not sell at a deep discount. To the extent that debt conversions are desirable, it might make sense for the official community to give or lend money to debtors in large amounts to enable a large-scale repurchase to take place. This is essentially the experiment now underway with Bolivia. We return to the possible involvement of the official community to support debt conversions in the next section.

Other forms of debt conversion have a similar effect as debt repurchases, though they may be of a very different appearance. In a debt-equity swap, for example, a potential foreign direct investor purchases some debt from the banks on the secondary market, and bringing the debt to the debtor country's central bank. The central bank purchases the debt using local currency, under the restriction that the domestic currency then be used to make a forelgn direct 
investment. As long as the central bank repurchases the debt from the investor at close to the secondary market price (1.e. at the price, converted Into local currency, that the Investor paid to the banks), then the transaction is essentially a cash repurchase of debt when viewed from the perspective of the central bank. The key (and perhaps only advantage) of such a mechanism from the debtor country's point of view relative to a direct repurchase of debt is that it allows the debtor to get around the sharing provision discussed earlier: ${ }^{22}$ 0therwise, debt-equity swaps have the same advantages and disadvantages of direct debt repurchases.

A new possible form of debt conversion that may be similar to a repurchase, though less costly to the debtor in terms of current cash flow, is an exit bond. With an exit bond, the creditor swaps his bank debt (say of $\$ 100$ ) for a bond of the debtor country with the same face value (1.e. same eventual principal repayment) but with a below-market coupon rate. The bond therefore has a contractual present value (1.e. a present value assuming no default) that is below the face value of the existing bank debt. ${ }^{23}$

Why should a creditor swap a bank loan for an exit bond of the same debtor that has a lower contractual present value? The bond is supposed to be superior to the existing bank debt for several reasons. First, holders of the bonds are explicitly relieved of the obligation to make contributions to "concerted lending" packages that may be negotiated between the banks and the country in the future. Second, the debtor undertakes, either explicitly or implicitly, to give the bonds a sentor status relative to the remaining bank debt 
(1.e. to fully service the bonds before servicing any of the bank debt). If the sentor status is credible, the bond may be a very safe claim. 24

Third, as discussed in a later section, the creditors as a group may benefit from the introduction of exit bonds, since certain efficiency gains may arise from the fact that the exit bonds reduce the debtor country's contractual debt service obligations. We shall see that the debtor country's ability and willingness to service its debts may well rise as the contractual obligations to do so fall.

Some Tax and Regulatory Aspects of Debt Conversions

There are two details that are important in understanding the full regulatory and financial ramifications of debt conversions. The first involves book accounting. As indicated earlier, debt conversions may or may not require immediate writedowns of book values of the banks' claims, depending on how the transaction is carried out. In general, if an asset is swapped for cash (a direct repurchase) or some non-debt claim (e.g. a debt-equity swap), the bank must book the new asset at its current market value, and write down any difference between the face value of the debt and the market value of the asset received in return. Thus, if debt with face value of $\$ 100$ is priced at $\$ 60$, and is traded for cash or equity worth $\$ 65$, the bank records a loss of $\$ 35$.

This loss is important for two reasons. It reduces the bank's book capital, which is the measure used for regulatory purposes. 
Second, the loss can be charged against taxes. If the bank pays the corporate tax rate on the margin (34 percent in 1988), then the tax savings would be worth $\$ 40 \times 0.34$, or $\$ 13.6$. Thus, the full value to the bank of selling a debt for $\$ 60$ would be $\$ 73.6$. Put differently, if the stock market is valuing the debt at $\$ 60$, the bank should be willing to sell the debt for $\$ 39$ in cash, since $\$ 39$ plus the tax saving of $\$ 21$ (equal to (1-.39) x.34), equals $\$ 60$.

If the bank debt is swapped for a new form of debt, however, then the accounting and tax rules may be different. If $\$ 100$ of bank debt at market interest rates is swapped for a $\$ 100$ exit bond with a sub-market interest rate, the bank does not in general have to write down the value of 1 ts claim unless and until the exit bond is sold on the market, at which time the writeoff would be the difference of $\$ 100$ and the price recelved for the bond. This accounting rule (known as FASB 15), gives the banks great flexibility with respect to exit bonds. They can choose the time to take the capital loss on the debt even after they swap the debt for exit bonds.

Why Debt Conversions are Attractive

There are reasons to belleve that debt conversions can make the creditors (as a group) as well as the debtors better off relative to the current situation in which the bank debt is kept on the books at full face value, whether or not it is fully serviced. ${ }^{25}$ For most countries, the current amount of debt significantly exceeds the expected discounted value of net debt servicing (i.e. debt servicing net of new concerted lending). We suggest that there may be 
important efficiency losses from keeping on the books an amount of debt far in excess of the amount that can reasonably be expected to be repald. These efficlencles losses are often Ignored, but they are a central aspect of the case for debt conversions.

The efficiency losses that we will discuss are widely recognized In the context of corporate or personal bankruptcy, but not yet in the context of excessive sovereign debt. There are good efficiency reasons why a corporation or Individual with greatly excessive debts is allowed to discharge those debts in the context of bankruptcy. In a corporate reorganization (1.e. a Chapter 11 proceeding), it is recognized that: (1) economic efficiency may dictate that an overly Indebted firm should continue to operate; but that (2) efficient operations require an explicit conversion of the debt into claims with a reduced contractual debt service obligation. (Otherwise, the firms cannot operate except in a crisis mode: they are denied suppliers credits; they are subjected to creditor lawsuits; they have a hard time collecting on accounts receivable; they cannot get new financing for investment projects; they cannot get workers to Invest In Job-specific training; and so forth). Bankruptcy courts do not tell the corporation to continue to operate with all of Its debt Intact, i.e. to simply roll over the debt and to "pretend" that it can service all of the debt in the future. It is recognized that the overhang of debt Itself prevents the smooth operation of the firm, to the ultimate detriment of the creditors.

The same kinds of efficlency losses apply in the context of sovereign debts. The overhang of the debt itself can hamper economic 
performance, even if the excessive debt is being concealed by concerted loans or by arrears. To see this, we will consider some simple illustrations. Suppose that a country owes $\$ 10$ billion of debt. The safe market interest rate is 10 percent. To begin, suppose that the country's debt servicing capacity (1.e. capacity to make a net resource transfer) every year $1 \mathrm{~s} \$ 600$ million assuming no change in policles. The country repays all that it can each perlod, though its repayment capacity may depend on the kinds of policies that it follows. The market value of the debt would simply be the discounted value of $\$ 600$ million, or $\$ 6$ billion at market interest rates. The secondary market price would therefore be $\$ 60$ per $\$ 100$ of debt.

In the present debt management arrangements (assuming no breakdown in negotiations, and without debt conversions), the country would pay the full $\$ 1$ billion of interest in the first year, and get a concerted loan of $\$ 400$ million, so that its net resource transfer would be $\$ 600$ million, which is its ability to pay. Next year, the debt would be $\$ 10.4$ billion, with interest due of $\$ 1.04$ billion. The country would again make a net resource transfer of $\$ 600$ milition, requiring a new concerted loan of $\$ 440$ mlllion. Each year the country would get a new concerted loan in order to keep the net transfer at $\$ 600$ million. The debt would eventually grow at a rate approaching 10 percent per year, the rate of interest. Obviously, the debtor and creditor are engaged in a simple "Ponzi scheme" to hide the fact of partial default.

Suppose that instead of this arrangement all of the debt were 
converted into exit bonds with 6 percent interest. The bonds would be perfectly safe, since the country would and could pay $\$ 600$ million per year on the bonds. There would be no defaults and no concerted lending, since the debt conversion would obviate the need for concerted lending. It would leave the position of the debtors and creditors unchanged with respect to net resource transfers each year. The debt conversion would impose no losses to the creditors regarding debt service receipts, and would offer the benefit to both debtors and creditors of avoiding the costs of negotiating the concerted loans each year.

Perhaps more Importantly, the debt conversion would avoid the risk of an actual breakdown in debt negotiations at some point in the future, leading to an outright default. The risk of a negotiating breakdown is present in most kinds of negotiations, but is particularly acute in the bargaining between banks and debtor countries, since both the creditors and debtors are negotiating on a wide variety of fronts, and so have the incentive to stake out "tough" positions to avoid the appearance of weakness in other settings. Actual breakdowns of negotiations (which have occurred with Nigeria, Peru, and several other countries) are very costly. The debtor's international trade can be hampered by a drying up international trade credits, or other forms of disruption. This disruption represents a debt- weight loss to both the debtor and the creditors, a loss that can be avoided by the debt conversion.

Note that the market price of debt will in general reflect the fears of such a future breakdown. In our example, therefore, in 
which the country can service 60 percent of the debt, the market price of the debt would generally sell at below 60 percent, say $\$ 55$ per $\$ 100$. Then, a switch to exit bonds would involve a capital gain from $\$ 55$ to $\$ 60$ that would be shared by the creditors and debtors.

Next, suppose that by undertaking a structural reform program in the current year, which would require the nation to forego $\$ 100$ million in current consumption, the country could raise its output, and therefore its debt servicing capacity, by $\$ 18$ million this year and every year in the future. Debt servicing capacity, and therefore debt servicing (under the assumption that the country pays all that it can) would rise to $\$ 618$ million per year. The secondary market value of the debt would rise to $\$ 61.8$ per $\$ 100$.

If this reform is carried out, the debtor would sacrifice consumption for the sake of the foreign creditors since the returns to the structural reform effort would be appropriated by future debt servicing. There would be little incentive to make such a structural change, and indeed it might be politically suicidal, since opposition parties would attack the government for sacrificing current consumption for the sake of foreign creditors. The key assumption of course is that the creditors would appropriate a large portion, if not all, of the improvements in the economy. This is a reasonable assumption. Concerted lending and reschedulings are granted to countries in dire economic difficulties. Once an economy improves, the debtor is expected to service its debts in full, and the debtor's bargaining power to resist debt servicing is diminis: No player, neither the banks, the IMF and World Bank, or the creditor 
governments, will excuse a country with a healthy economy from debt servicing, on the grounds that it was once in trouble and chose to undertake needed reforms!

Could the reforms be financed by the foreign creditors in order to increase the country's debt servicing capacity, rather than via a reduction in debtor-country consumption? Probably not. Supposing that $\$ 100$ million is lent to the country in addition to the $\$ 400$ million of interest refinancing (the overall concerted loan would be $\$ 500$ million). There is no guarantee that the structural reforms would actually be undertaken. The country might "promise" to undertake the reforms, receive the loan, use the money for consumption purposes instead, and continue to pay $\$ 600$ million in net resource transfers in the future. They would benefit from this policy choice, by raising current consumption by $\$ 100$ million at no real future cost. Since promises to reform are notoriously difficult to regulate, (most IMF and World Bank conditionality requirements are not met by borrowing countries), it is a good bet that such lending would be dangerous indeed, and thus would not be undertaken.

Now suppose that the debt conversion exercise is undertaken instead. The contractual debt burden is reduced to the level $\$ 600$ million per year through the use of exit bonds. Now, if the country undertakes the reform effort, it would reduce current consumption by $\$ 100$ million, but increase future consumption potential by $\$ 18$ million per year. The foreign creditors would no longer appropriate the benefit, since their claims have been reduced to a fixed $\$ 600$ million by the debt conversion. As long as the consumers' rate of 
time discount is sufficiently low, the reform will now look attractive. The creditor's welfare is unchanged by the debt conversion, and the debtor's is raised.

As a result of the efficiency gains, it would generally be possible to structure the debt conversion to benefit both the debtor and the creditors. For example, the debt worth $\$ 60$ in this example could be swapped 1nto exit bonds worth $\$ 61$ (e.g. paying 6.1 percent Interest), still leaving the debtor with enough incentive to carry out the reforms.

The key point of this extended example is that an overhang of debt creates various inefficiencies. First, the debt overhang requires continuous and costly renegotiation of the debt. Second, it raises the spectre of a costly breakdown of negotiation, which would disrupt the trading arrangements of the debtor, and thereby impose costs on both the debtor and the creditors. Third, and perhaps most important, the debt can act as a heavy tax on economic reform. Under the current arrangements, the returns to reform are appropriated heavily, if not entirely, by the forelgn creditors. The result is twofold: (1) no Individual government has an incentive to undertake adjustments; and (2) political parties that are opposed to reform have an attractive case to take to the electorate. This latter concern is far from abstract. In recent legislative elections, the reformist govermment of President Alfonsin in Argentine lost heavily to the Peronists, who have been arguing against reforms to increase forelgn debt repayments, urging a debt moratorium instaad. 
A Crucial Caveat on Exit Bonds

The previous discussion has highlighted the potential usefulness of exit bonds. We have given examples in which the conversion of all bank debt into exit bonds could reduce the contractual obligations of the debtor country while at the same time maintaining, or even raising, the market value of the resulting claims held by the creditors. The example was chosen to make this point, but for this reason it may mislead as well. In a more general setting, the conversion of bank debt into exit bonds may result in a fall in the value of the creditors' claims rather than a rise, thereby undercutting the case for exit bonds.

Consider an additional illustration. Suppose that a debtor country will be able (and willing) to repay its debts fully if world commodity prices recover (probability 0.6 ), end will default entirely if commoditles prices stay the same or fall further (probability 0.4). $\$ 100$ of debt would sell for $\$ 60$ in the secondary market. Now suppose that the debt is converted to exit bonds, carrying a coupon interest rate at 60 percent of the market interest rate. The contractual present value of a $\$ 100$ long-term bond would be reduced to $\$ 60$. What would be the new merket value of the creditors' claims? Evidently, the new exit bonds would also have a 60 percent chance of being fully serviced, and a 40 percent chance of being fully defaulted. Thus, the exit bonds would sell at a 60 percent discount relative to the contractual obligations of the bonds. In other 
words, the market price would by 60 percent of $\$ 60$, or $\$ 36$. Obviously, in this case, the creditors lose substantially by giving up their bank claims (worth $\$ 60$ ) for an exit bond (worth $\$ 36$ ).

Therefore, a discount on the bank debt in the secondary market does not mean that creditors can automatically benefit (or at least not suffer) from a conversion of debt into exit bonds. In the example that we just cited, there is no efficlency gain to making the debt conversion, since payoffs depend purely on the exogenous world commodity price, not on the policies of the debtor. There is however a loss to the creditors, since with the conversion to exit bonds, the banks give up the chance of recelving the full $\$ 100$ repayment of their debt in the event of favorable world commodity prices. Technically, part of the value of the creditors' claims on the country is the option value of sharing in high commodities prices. When the debt is converted Into exit bonds with a lower contractual value, part of that option value is lost.

Exit bonds therefore have the following minuses and plusses when viewed from the perspective of the creditors as a group. On the negative side, since exit bonds reduce the contractual present value of future debt repayments, the banks lose the option value of getting fully or substantially repaid on their bank debt if exogenous events are highly favorable. On the positive side, the exit bonds offer various efficiency benefits, which can raise the market value of the resulting claims. To reiterate, these efficiency gains include: avolding the costs of continuous debt negotiations, avolding the chance of a costly breakdown in future debt negotiations, and 
stimulating economic reform in the debtor country. The balance of costs and benefits depends on the relative importance of these considerations.

We are Inclined to belleve that the benefits of debt conversion considerably outwelgh the posstble costs, though our reasons are necessarily impressionistic, and must be considered on a case-by-case basis. The 50 percent discount on bank debt for most countries reflects the fact that the debt is twice too large to be serviced with regularity, rather than the fact that exogenous events will result in all or no repayment with probability 0.5. In other words, the option value of walting for full or nearly full repayment is of little value. Moreover, as we have pointed out, it is likely to be seriously self-defeating, since if the creditors wait for full repayment, the debt overhang will stifle reform and tend to bring to power less reformist and more radical regimes, that indeed will choose to suspend all debt repayments.

Put yet another way, if the creditors really face a probability distribution involving complete versus no repayments on the debt, it is a probability distribution that they themselves can influence. A reduction in the contractual debt burden through some form of debt conversion will bolster the political standing of those who would repay the debt.

Debt Conversions and Public Policy

To the extent that debt conversions are desirable for Improving 
the effictency of the debtor economles, there may be a role for public policy is facllitating such transactions. At the minimum, the regulatory environment can be modffied so that arbitrary book value calculations do not stand in the way of desirable exchanges.

Many commentators have proposed going further, and using public money to smooth the debt conversion operations. In one popular proposal, the debt conversion would be intermediated by a new International debt facility. The facility (which could be part of the World Bank for example) would accept the exit bonds of the debtor country, and 1ssue its own bonds to the commerclal banks in return for the existing bank debt, which then would be extinguished. The country would owe money to the facility in the form of exit bonds. The facility would owe money to the banks in the form of guaranteed bonds. The banks would get a safe claim (the bond of the debt facility) rather than a risky exit bond of the debtor country.

This proposal is obviously nearly identical to two other alternatives which have also been discussed. The first alternative is that the offictal creditor communtty (e.g. the World Bank) would provide a guarantee on the exit bonds issued by the debtor country. The second alternative is that the offlcial creditor community would lend the debtor countrles the money necessary to make cash repurchases of debt in the secondary market. In all three cases, the contractual debt burden of the debtor country is reduced in line with the discount on its debt in the secondary market, and the claims on the debtor country are effectively shifted to the official creditor communtty and away from the commercial banks. 
It is easy to see that the capital cost to the official community of this operation would be the difference in value of its own bonds (which would sell at par, since they are a safe asset) and the exit bonds of the debtor country. ${ }^{26}$ Suppose, for example, that the country's debt now sells at $\$ 60$ per $\$ 100$. If the facility issues $\$ 60$ of guaranteed bonds to the banks, and accepts exit bonds from the debtor country with a contractual value of $\$ 60$, the facility's net worth will depend on the actual market value of the debtor country's exit bonds relative to the $\$ 60$ contractual value. We have given examples in which the $\$ 60$ of exit bonds will Indeed be worth the full $\$ 60$, (with no costs to the facility, and cases in which the bonds would be worth only $\$ 36$ (with the facility losing $\$ 24$ in present value terms).

Why is such a facility needed at all? The main reason is that a large-scale debt conversion poses significant collective action problems that can best be overcome with official intervention. Bankers' fears about regulatory problems, the legal status of exit bonds, the problem of contagion effects (in which terms to one country influence negotiations with other countries), and the difficulty of collective decislonmaking among the a large number of banks, make it difficult to carry out a large-scale debt conversion without considerable support of the official community. Therefore, the significant efficiency gains that might be generated by a debt conversion are not achieved.

Importantly, the likely costs to the official community of intermediating a large-scale conversion would be modest. Suppose 
that each creditor country participates in the international debt facllity in proportion to the exposure of its banks in the problem debtor countries. As we saw in Table 1, U.S. banks hold approximate1y $\$ 57$ billion In claims on governments of the problem debtor countries. The secondary market value of those claims was $\$ 32$ billion in July 1987. If the debt facllity gave the U.S. banks guaranteed bonds worth $\$ 32$ billion in return for the debt, and accepted exit bonds from the debtor countries with a contractual obligation of $\$ 32$ billion, the capital cost to the U.S. would be the market discount on the $\$ 32$ billion of exit bonds. At best, the claims on the LDCs would be worth the full $\$ 32$ billion: there would be no residual cost to the U.S. At the very worst, the bonds would sell at the same discount as the original bank debt (1.e. at 55 percent of contractual value). The claims on the LDCs in that case would be worth $\$ 17.60$ billion, and the transaction would cost the U.S. government $\$ 14$ billion. Presumably, this capital loss could be amortized over many years, so that U.S. taxpayers would end up paying $\$ 1$ - $\$ 2$ billion each year for several years.

Even this upper limit of $\$ 14$ billion seems a modest cost in order to achieve a reduction in LDC debt to the secondary market levels for all thirty problem debtor countries in Table 1. Consider what Is achieved from the U.S. perspective: (1) the debt is reduced to levels deemed manageable from the point of the view of the market; (2) the U.S. banks are taken out of the game, and out of risk, without imposing further losses than have already been incurred; (3) the potential is enhanced for significant efficiency gains in the 
debtor countries by virtue of eliminating the debt overhang; (4) relatedly, the political posteions of moderates in the LDCs is bolstered relative to political forces that are urging a suspension of debt servicing; and (5) by the same token, new democratic regimes In much of Latin America and the Philippines would likely be strengthened by a reduction of thelr contractual debt servicing obligations. Finally, this kind of relief is a very efficient form of foreign ald, since the U.S. contributions would also be matched by the other creditor governments. The Germans, Japanese, British, and other countrles, would also be contributing their pro rata share, so that the U.S. would avoid carrying an undo part of the burden. To look at the costs from the point of the view of the entire creditor communty, we turn to the data in Table 18. As of the end of 1985, the world's financial institutions (almost exclusively banks), had medium and long-term claims on the governments of the problem debtor countries of $\$ 194$ billion, with a secondary market value of $\$ 105$ billion. Thus a complete swap of debts into exit bonds for the thirty countries in Table 18 would require official guarantees of $\$ 105$ billion. At best, the capital cost of these guarantees will be zero: the debtor countries will fully service the reduced burden of the exit bonds. At the very worst, the exit bonds would be valued at the same discount as the current bank debt, about $\$ 54$ per $\$ 100$ of face value (the discount is slightly different from the discount for the U.S. banks because of the composition of the global portfolio). Then, the capital loss Internationally would be on the order of (1-.54) $x \$ 105$, or $\$ 48$ billion for the entire creditor community, of which the U.S. 
Table 18. Secondary Market Value of Claims of Financial Insitutions on the Problem Debtor Nations.

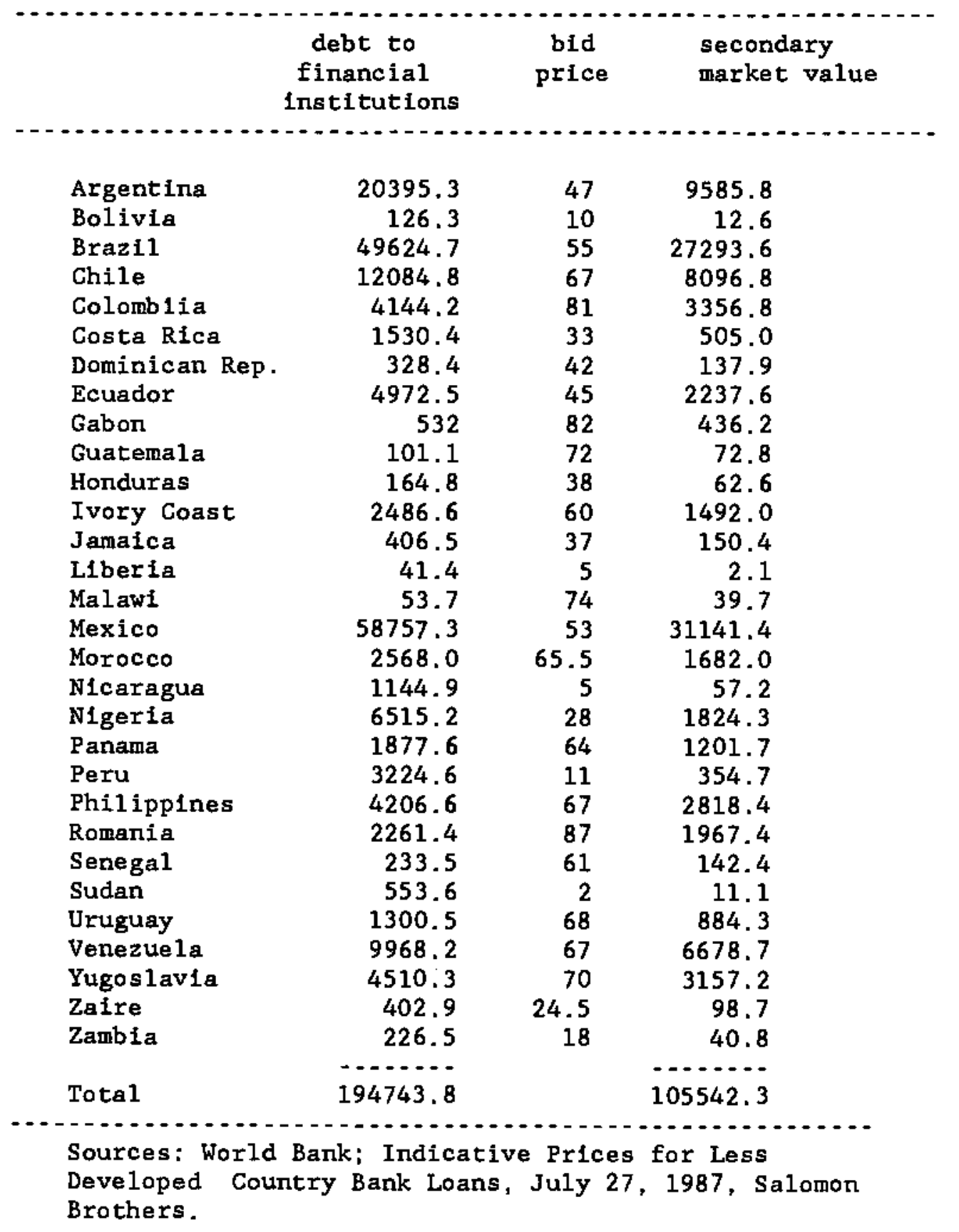


share would be approximately $\$ 14$ billion.

Conclusions

The major theme of this paper is that the commerclal banks have weathered the debt crisis, while many debtor countries remain in economic paralysis or worse. There is a growing consensus that much of the LDC debt will not be fully serviced in the future, and that consensus is reflected in at least two ways: in the discounts observed in the secondary market prices for LDC debt, and in the discounts in the stock market pricing of banks with exposures in the LDCs.

The fact that the bank share prices of heavily exposed banks are already discounted in reflection of the decline in value of the LDC claims demonstrates that the banks could absorb a significant book loss on their LDC exposure.

Our analysis suggests that certain debt conversion schemes now under discussion could offer debt rellef to the debtor countries without causing a further deterforation in the market values of the commercial banks. 
1. See J. Sachs, "Managing the Developing Gountry Debt Crisis, Brookings Papers on Economic Activity, 1986:2, for an overview of the debt crisis and the management of the crisis by the creditor countries.

2. To give an 1dea of the global distribution of bank claims in the problem debtor countries, Latin America has about $\$ 200$ billion of bank debt outstanding, of which about $\$ 75$ billion is owed to U.S. banks, $\$ 30$ billion to Japanese banks (w1th $\$ 13$ in Mexico and $\$ 10$ in Brazil), $\$ 40$ billion to U.K. banks, and the remaining $\$ 55$ billion or so divided among German, French, Canadian, Swlss, and other banks. The estimate for Japan is from Doherty, "Japan's Role in the International Debt Crisis", Japan Economic Institute, and for the U.K. from the IMF International Capital Markets, 1986.

3. The term "debt forgiveness" is used to refer to any restructuring of the debt that reduces the expected discounted value of future payments. Interest capitalization refers to any scheme by which a portion of interest due is automatically relent to the debtor for later payment. Interest capitalization is distinguished from "involuntary lending" packages, in which loans are made on an ad hoc basis so that the country can finance some of the Interest due.

4. Since completing the analysis in this paper, the secondary market prices have fallen further for most of the debtor countries. As of October 6, 1987, Salonon Brothers quoted the following prices for the largest countrles: Argentina, 34; Brazil, 38; Mexico, 47; and the Phillppines, 55. Some of the reasons for the further drop between July and October 1987 include: the toughening of the Brazllian negotiating position in the fall of 1987 (Including Brazil's call for a major conversion of debt to exit bonds at sub-market Interest rates); the Peronist electoral victory in Argentina in September 1987; the political instability in the Philippines; and the sharp rise in U.S.denominated interest rates.

5. An initial attempt to analyze the links of stock market prices and IDC debt was carried out by Steven Kyle and Jeffrey Sachs, "Developing Country Debt and the Market Value of Large Commercial Banks," NBER Working Paper No. 1470, September 1984. That study, which used data unt1l 1983:III, also found a significant negative effect of LDC exposure on bank share prices.

6. Of course, many of these problems pre-dated the debt crisis, and Indeed were contrlbuting factors to the onset of crisis, a point stressed in J. Sachs, "External Debt and Economic Performance in Latin America and East Asla", Brookings Papers on 
Economic Activity, 1985:2. In most cases, the excessive budgetary deficits reflect deep social and political divisions within the debtor countries that have been exacerbated by the need to service a heavy forelgn debt burden.

7. In Latin America, Chile has been the main beneficlary of the rise in metals prices, since copper accounts for more than 40 per cent of Chile's merchandise exports. Copper prices have risen from 64 cents per pound at the end of 1985, to a price of 91 cents per pound in October 1987.

8. For a discussion of the budgetary burden resulting from the foreign debt, see Helmut Reisen and Axel Van Trotsenburg, "The Budgetary and Transfer Problem of Major Debtor Countries", OECD Development Centre, Paris 1987, and J. Sachs, "Trade and Exchange Rate Policies in Growth-Oriented Adjustment Programs," NBER Working Paper No. 2552, 1987.

9. Mexico received approximately $\$ 6$ billion in bank credits and Argentina recently signed an agreement for $\$ 2$ billion in new bank credits. These amounts correspond to approximately one year's interest payments on medium and long-term sovereign debt.

10. Moreover, the banks more than fully refinanced Chile's interest payments during 1983-84 (1.e. the "converted lending" to Chile in 1983-84 exceeded Chile's interest payments), so that Chile actually received a net resource transfer from the commercial banks as late as 1984. Interestingly, concerted lending to Chile has been more generous on average (when the new lending is measured as a ratio to the existing debt) during 198386 than has concerted lending to any other problem debtor country.

11. In her speech upon the opening of the Philippine Congress, President Aquino declared, "We cannot help but feel our forelgn creditors took undue and unfair advantage of the internal differences we had with factions intent on subverting this Government and destroying our democracy." (As quoted in the Financial Times, July 28, 1987). The first act of both houses of the new Philippine Congress was to call for an investigation into the forelgn debt.

12. See the IMF 'Internatinonal Capital Markets,' December 1986, for details on spreads and Maturities in debt reschedulings through 1986. See 'The Economist' (March 22, 1987, p. 18) for an update.

13. Non-accrual loans are loans in which interest servicing is behind schedule or sufficlently sporadic so that interest is credited to the bank only as it is recelved (i.e. on a cash 
basis), rather than the more typical procedure of crediting interest as it accrues.

14. For a good discussion of the issues, see George J. Benston, et.al., Safe \& Sound: Perspectives on Banking, MIT Press, 1986

15. Consider a bank that has deposits of $\$ 95,10 a n s$ of $\$ 100$, and primary capital (In this case equal to shareholder's equity) of \$5. A 5 percent reduction in the value of the assets wipes out 100 percent of the bank capital!

16. The exposures to the Brazilian and Mexican public sectors at the end of 1983, as a percentage of primary capital, were rather large for many of the large banks. For Brazil, the exposure ratios were as follows: Bank of America, 28 percent; Chase 1; Chemical 23; Citicorp 35; and Manufacturers Hanover, 36. For Mexico, the ratios were: Bank of America, 21; Chase, 3; Chemical, 27; Citicorp, 8; and Manufacturers Hanover, 46.

17. For a further discussion, see the IMF International Capital Markets, 1984, p. 17-18, and later 1ssues, and the Wa11 Street Journal, "U.S. Bank Regulators are Called Likely to Require Write-Down of Braz11 Loans", September 1, 1987.

18. Thomas Hanley of Salomon Bro.hers is quoted in Fortune Magazine (March 30, 1987, p. 104) as declaring: "The discount [in the stock market] is even greater than the price concessions accorded Third World debt currently trading in the secondary market."

19. Mchael Metz, portfolio strategist of Oppenheimer \& Co., quoted in the Washington Post, May 21, 1987.

20. This latter assumption is made to ease problems of data collection.

21. An example is a follows. Instead of using the $\$ 60$ cash to repurchase the debt, the debtor country puts the cash in a custodial account managed by the creditors, to guarantee a bond with sub-market interest rates that has a present value equal to the sale price (e.g. a $\$ 100$ face value bonc, with a coupon rate 40 percent below market interest rates, that gives the bond a market value of $\$ 60)$. The creditors then swap their $\$ 100$ of debt for the guaranteed ("defeased") bond, also with a face value of $\$ 100$, but a safe market value of $\$ 60$. Under standard accounting rules, specifically FASB 15 , a swap of $\$ 100$ of debt for $\$ 100$ of bonds of the same debtor, generally does not require a writedown 
In book values of the claim.

22. Until recently, most central banks were redeeming the debt at close to par, rather than at clase to the secondary market price. This gave the foreign investor the spread between the secondary market price and the face value of the debt. In principle, a repurchase at par may act as an investment incentive, though as with many incentive schemes, the largest effect was to give a large lump-sum transfer to infra-marginal investors that would have invested in the country anyway. Recently, central banks have been finding ways to recapture most of discount on the debt. They have done this either by repurchasing the debt at close to the secondary market price, or by auctioning the right to participate in a debt-equity swap among potential foreign investors, thereby recapturing the surplus previously accruing to the forelgn investors.

23. Note that in contractual terms, the bank claim has a present value equal to its face value, since it carries a market rate of interest.

24. Consider the the case of Brazil for example, with about $\$ 70$ billion of bank debt, and annual net resource transfers to the banks in recent years of about $\$ 6$ billion. If Brazil were to convert $\$ 10$ billion of its debt into exit bonds with a very long maturity and a fixed interest rate of 6 percent, given a safe market rate of 10 percent, the interest due on the bonds would be $\$ 600$ million per year. If the $\$ 600$ million is credibly senior to the remaining bank debt, there would be little doubt about Brazil's capacity to service the bonds, since the $\$ 600$ milition is far less than Brazil's revealed annual capacity and willingness to pay. The bonds would therefore be a relatively safe asset, and would therefore be priced at about $\$ 60$ per $\$ 100$ of principal (that is, $6 / 10$ of market interest rate $x \$ 100$, assuming a long maturity on the bond). Assuming that bank claims on Brazil are now selling at below $\$ 60$ per $\$ 100$, individual banks should be willing to swap their bank debt for the exit bonds.

25. The argument in this section, that debt conversions or debt rellef, can provide efficlency gains for both debtors and creditors, was first argued in J. Sachs, "The Debt Overhang of Developing Countries," forthcoming in the Memorial Volume for Carlos Diaz Alejandro, to be published by the WIDER Insitute, Helsinki, 1988. Another recent paper that explores a similar theme is Paul Krugman, "Bootstrap Debt Relief," mimeo, MIT.

26. The facility might even sell off some or all of the exit bonds in the open market, to realize the capital loss, and reduce future risks. 